\title{
Assessment of Heat Stress and Cloudiness Probabilities in Post- Flowering of Wheat and Canola in The Southern Cone of South America
}

\author{
Gonzalo Martín Rivelli ( $\nabla$ grivelli@agro.uba.ar) \\ FAUBA https://orcid.org/0000-0001-9419-5918 \\ María Elena Fernández Long \\ FAUBA \\ Leonor Gabriela Abeledo \\ FAUBA \\ Daniel Calderini \\ Universidad Austral de Chile \\ Daniel Julio Miralles \\ FAUBA \\ Deborah Paola Rondanini \\ FAUBA
}

\section{Research Article}

Keywords: High temperature, dimming, combined stress, temperate crops, climate change

Posted Date: April 1st, 2021

DOI: https://doi.org/10.21203/rs.3.rs-377201/v1

License: (c) (i) This work is licensed under a Creative Commons Attribution 4.0 International License. Read Full License

Version of Record: A version of this preprint was published at Theoretical and Applied Climatology on July 11th, 2021. See the published version at https://doi.org/10.1007/s00704-021-03694-x. 


\section{Abstract}

Episodes of heat stress constrain crop production and will be aggravated in the near future according to short and medium-term climate scenarios. Global increase in cloudiness has also been observed, decreasing the incident solar radiation. This work was aimed to quantify the probability of occurrence of heat stress and cloudiness, alone or combined, during the typical post-flowering period of wheat and canola in the Southern Cone of South America. Extended climate series (last 3-5 decades with daily register) of 33 conventional weather stations from Argentina, Brazil, Chile and Uruguay $\left(23^{\circ} \mathrm{S}\right.$ to $\left.40^{\circ} \mathrm{S}\right)$ were analysed considering the period from September to December. Two different daily events of heat stress were determined: i) maximum daily temperature above $30^{\circ} \mathrm{C}$ $\left(\mathrm{T}>30^{\circ} \mathrm{C}\right)$, and ii) $5^{\circ} \mathrm{C}$ above the historical average maximum temperature of that day $\left(T+5^{\circ} \mathrm{C}\right)$. A cloudiness event was defined in our work as incident solar radiation $50 \%$ lower than the historical average radiation of that day $(\mathrm{R} 50 \%)$. The $\mathrm{T}>30^{\circ} \mathrm{C}$ event increased its probability of occurrence throughout the post-flowering phase, from September to December. By contrast, the risk of $\mathrm{T}+5^{\circ} \mathrm{C}$ event decreased slightly, just like for R50\%, and the higher the latitude, the lower the probability of R50\%. The T>30 ${ }^{\circ} \mathrm{C}$ plus R50\% combined stresses reached greater cumulated probabilities during post-flowering, compared to $\mathrm{T}+5^{\circ} \mathrm{C}$ plus $\mathrm{R} 50 \%$, being $42 \%$ vs. $15 \%$ in northernmost locations, $26 \%$ vs. $19 \%$ in central (between $31^{\circ} \mathrm{S}$ to $35^{\circ} \mathrm{S}$ ), and $28 \%$ vs. $1 \%$ in southernmost locations, respectively. A curvilinear relationship emerged between the monthly probability of combined stresses and the number of days with stress per month. In summary, $\mathrm{T}>30^{\circ} \mathrm{C}$ was the most frequent thermal stress during post-flowering in wheat and canola. Both combined stresses had a noticeable risk of occurrence, but $\mathrm{T}>30^{\circ} \mathrm{C}$ plus R50\% was the highest. Evidence of the recent past and current occurrence of heat stress individually, and its combination with cloudiness events during post-flowering of temperate crops, serves as a baseline for future climate scenarios in main cropped areas in the Southern Cone of South America.

\section{Introduction}

The Southern Cone of South America is a vast region of approximately 3 million $\mathrm{km}^{2}$ between $23^{\circ} \mathrm{S}$ and $40^{\circ} \mathrm{S}$. This huge area runs from subtropical zones such as southern Brazil and northern Argentina ( $23^{\circ} \mathrm{S}$; Tropic of Capricorn) to temperate (Uruguay) and cold regions of central-southern Argentina and Chile $\left(40^{\circ} \mathrm{S}\right)$ (Fig. 1). Plains and river valleys with extensive agriculture coexist with natural areas harbouring wild plant species with a wide range of biodiversity. With a population $\sim 276$ million people in the Southern Cone, food production is a priority. Wheat and canola are the main cereal and oilseed crops, respectively, both cultivated during winter-spring in this region of South America. Wheat production in the Southern Cone (25.8 million $\mathrm{t}$ ) accounts for $3.5 \%$ of wheat world production and it is cropped in 8.3 million ha, whereas canola production is 0.39 million t $(0.5 \%$ of world), harvested in 0.16 million ha (FAO, 2020). These key temperate crops and their production are challenged by the scenarios of climate change in the Southern Cone.

According to the Intergovernmental Panel on Climate Change (IPCC, 2018), the global average temperature is currently increasing by $0.2^{\circ} \mathrm{C}\left( \pm 0.1^{\circ} \mathrm{C}\right)$ per decade. A changing climate leads to variation in the frequency, intensity or duration of weather and climate extremes (Marengo et al., 2014) and these changes impact negatively on crop productivity and food security at both global and regional scale (FAO 2015). For the main production areas of temperate annual crops in the Southern Cone, higher daytime temperatures are forecast for spring and summer, accompanied by the occurrence of extreme temperatures (Sillmann et al., 2013; Feron et al., 2019). For the end of the 21 st century, average temperatures were projected to increase by $4^{\circ} \mathrm{C}$ for the Southern Cone (IPCC, 2013). The scenarios of temperature increase for the eastern side of the Andes mountains are expected to be warmer in the second half of the 21st century (Rusticucci and Renom, 2007; Barros et al., 2015), with a higher trend for minimum temperatures ca. $0.14^{\circ} \mathrm{C}$ per decade (i.e., warmer nights) during the spring season in the Argentinean Pampas (García et al., 2018).

Temperature and solar radiation are factors that are highly influenced by the effects of climate change. Temperature is closely associated with solar radiation reaching the Earth's surface. Therefore, temperature and radiation to which a crop is exposed depend on the location and the time of year when the crop is growing in the field. Latitude is one of the main geographical factors determining the annual amount of solar radiation and consequently mean temperature (Linacre and Geerts, 1997; Barry and Chorley, 2003). In the Southern Cone, the highest values of annual solar radiation and annual average temperature are found in the Tropic of Capricorn $\left(23^{\circ} \mathrm{S}\right)$, attenuated at higher latitude (Reed, 1929; Barry and Chorley, 2003).

In addition to temperature increase, solar dimming, which is defined as the decrease in the amounts of solar radiation reaching the Earth's surface, due to increased cloudiness, pollution and rain, has become a challenge to crop production. Although cloudiness is not a universal explanation for solar dimming, it is the largest modulator of solar radiation in the atmosphere, causing multi-decadal changes of incident solar radiation fluxes (Norris and Wild, 2007; Bartoszek et al., 2020). A reduction of solar radiation of about 1.3\%

Page $2 / 24$ 
per decade or about $7 \mathrm{~W} \mathrm{~m}^{-2}$ was already recorded for the period 1950-1980 in land stations around the world (Gilgen et al., 1998; Liepert, 2002; Raichijk, 2011; Matuszko and Stanisław, 2015). This has been supported by a $0.51 \pm 0.05 \mathrm{~W} \mathrm{~m}^{-2}$ decrease of solar radiation per year, at a rate of $2.7 \%$ per decade during the last 50 years of the 20th century (Stanhill and Cohen, 2001). Apparently, this has been a global phenomenon, as similar results were reported for specific areas such as the former Soviet Union (Russak, 1990; Abakumova et al., 1996), the Mediterranean Basin (Aksoy, 1997; Omran, 2000), USA (Liepert, 2002), China (Ren et al., 2005), and southern Africa (Power and Mills, 2005). In the Southern Cone, solar reduction was estimated by $0.59 \mathrm{~W} \mathrm{~m}^{-2}$ per year between 1960 and 1990 (Stanhill and Cohen, 2001). However, no information is available about cloudiness events across the latitudes in the Southern Cone for recent years. Cloudiness events are relevant for crop production, as they affect the photosynthetic capacity and, consequently, the growth of crops. The convergent events of higher temperature and lower radiation due to both dimming and cloudiness have the consequence of lower intercepted radiation by crops and biomass production.

Flowering time of wheat and canola in the Southern Cone typically occurs from early (northern Argentina and southern Brazil) to late (Uruguay and central-southern Argentina and Chile) spring (Pan et al., 2009; Miralles et al., 2014; Pengue, 2015; Mera et al., 2015; Gazzano et al., 2019). The weather conditions occurring immediately at pre and post-flowering in wheat and canola, often from September to December, are key, since physiological processes during these stages define grain yield. Grain yield in both crops is closely associated with the number of grains per area (Tommey and Evans, 1992; Diepenbrock, 2000; Fischer, 2007), which is defined in a particular period called "critical period", around flowering for wheat (Fischer, 1985) and post-flowering for canola (Kirkegaard et al., 2018). Grain growth takes place during the post-flowering period (from flowering to physiological maturity), in which grain weight and quality are defined. High air temperature and low solar radiation are two well-known key factors that reduce grain yield in both crops (Brocklehurst et al., 1978; Evans et al., 1978; Wardlaw et al., 1995; Aksouh-Harradj et al., 2006; Labra et al., 2017).

Although both global dimming and temperature increases are expected, little effort has been devoted to evaluating both climate variables together during the post-flowering period in wheat and canola, when high-temperature events are most likely to occur. After flowering, different evidence found in the literature, applying shading treatments to reduce incident solar radiation from 50 to $80 \%$, produced a reduction in biomass accumulation (Savin and Slafer, 1991; Labra et al., 2017), grain weight (Serrago et al., 2013; Iglesias and Miralles, 2014) and/or grain yield (Fischer, 1985; Kirkegaard et al., 2018), depending on the capacity of both crops to cope with stress (Zhang and Flottmann, 2015; Asseng et al., 2017). Regarding the known effects of high temperatures on crop physiology, two different thermal stresses arise during the post-flowering period in temperate crops: moderately high temperatures throughout the whole period, and very high daytime temperatures during short periods, with $30^{\circ} \mathrm{C}$ as thermal threshold (Wardlaw and Wrigley, 1994 ; Tahir et al., 2006; Wahid et al., 2007). High temperature during post-flowering reduces grain weight in wheat and canola (Lizana and Calderini, 2013; Asseng et al., 2017; Dreccer et al., 2018; Lilley et al., 2019). The ooccurrences of scenarios of maximum high daytime temperatures in the typical post-flowering period of wheat and canola have not been studied for southern South America. In addition, scenarios of combined stresses of high temperature and cloudy days have been even less evaluated.

The objective of this work was to quantify the probability of occurrence of events of heat stress and cloudiness, alone and combined, during the post-flowering period of wheat and canola in the Southern Cone of South America, through the analysis of historical climate series recorded in 33 locations of the South Cone from $23^{\circ} \mathrm{S}$ and $40^{\circ} \mathrm{S}$. We hypothesise that during the post-flowering period of wheat and canola, (i) the probability of two different events of heat stress, such as maximum daily temperatures above $30^{\circ} \mathrm{C}\left(\mathrm{T}>30^{\circ} \mathrm{C}\right)$ and increase of $5^{\circ} \mathrm{C}$ above the daily maximum historical average $\left(T+5^{\circ} \mathrm{C}\right.$ ), is higher in locations at lower latitude, (ii) $\mathrm{T}>30^{\circ} \mathrm{C}$ and $\mathrm{T}+5^{\circ} \mathrm{C}$ present similar probability for a given location, (iii) cloudiness event (R50\%) differs with latitude and throughout the post-flowering period, and (iv) each location has similar behaviour throughout post-flowering regarding the probability of occurrence of both types of events combined.

\section{Materials And Methods}

\subsection{Selected sites, climate series and analysis period}

This study evaluated the meteorological information of 33 representative locations of the production areas of wheat and canola, from 4 countries of the Southern Cone of South America: Argentina, Brazil, Chile and Uruguay (Table 1). To facilitate the presentation of the data, the studied region was divided into 3 areas according to their latitude: north (covering latitudes from $23^{\circ} \mathrm{S}$ to $31^{\circ} \mathrm{S}$ ), central (from $31^{\circ} \mathrm{S}$ to $35^{\circ} \mathrm{S}$ ) and south (from $35^{\circ} \mathrm{S}$ to $40^{\circ} \mathrm{S}$ ) (Table 1 and Fig. 1). 
Historical climate series were recorded by the National Meteorological Service (SMN, Argentina), the Agronomic Institute of Paraná (IAPAR, Brasil), the Institute of Agricultural Research (INIA, Chile) and the National Institute of Agricultural Research (INIA, Uruguay). Databases comprise records of daily maximum and minimum temperature $\left({ }^{\circ} \mathrm{C}\right.$ ) and sunshine duration (hours) covering the last $30-57$ years (Table 1).

The analysis accounts for the period between September $1^{\text {st }}$ and December $31^{\text {st }}$ to cover the typical post-flowering period (i.e., from flowering to physiological maturity) for wheat and canola of each location: September to October in the northern, October to November in the central and November to December in the southern areas (Table 1 and supplementary Fig. S1).

\subsection{Phenology of wheat and canola in the Southern Cone}

In locations of Argentina, dates of flowering (F) and physiological maturity (PM) of wheat and canola were predicted through the CRONOS@ software (cronos.agro.uba.ar). Hence, a likely planting date was previously established for each location and genotype choice. Sowing date within the Pampas Region is usually from early June (in the lower latitude locations within the region) while late sowing date is late July for locations in higher latitudes. We worked with a spring cultivar for wheat and canola. The source for most frequent dates of $\mathrm{F}$ and PM of wheat and canola for Brazil, Chile and Uruguay were the literature and national web pages (Miralles et al., 2014; Mera et al., 2015; http://www.atlanticasementes.com.br; http://www.inia.org.uy).

\subsection{Heat stress and cloudiness events}

In order to account for high temperature stressful conditions from September $1^{\text {st }}$ to December $31^{\text {st }}$, the probability of daily heat events was calculated by: i) maximum daily temperatures above a threshold value of $30^{\circ} \mathrm{C}\left(\mathrm{T}>30^{\circ} \mathrm{C}\right)$, and (ii) daily maximum temperature above $5^{\circ} \mathrm{C}$ of the daily maximum historical average $\left(T+5^{\circ} \mathrm{C}\right)$. Cloudiness probability was calculated quantifying days with global solar radiation $\leq 50 \%$ the historical daily average radiation (R50\%). The global solar radiation data of each location was calculated through the data of sunshine duration, according to the Angström model (1924) as recommended by the World Meteorological Organization (WMO, 2008) (Eq. 1).

$\mathrm{Q}=\mathrm{Q}_{\mathrm{o}}(\mathrm{a}+\mathrm{b} \cdot \mathrm{S})$ Eq. 1

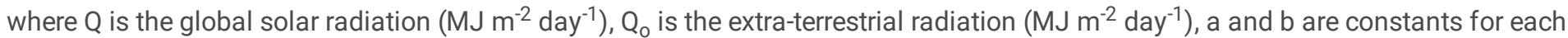
weather station, and $\mathrm{S}$ is the relative sunshine duration (hours of sun with respect to duration of the day).

The probability of occurrence of an event for a given day was calculated as:

$P_{i, j, k}=\frac{\sum_{i=0}^{n} x_{i, j, k}}{n_{j}}$

where: $P i, j, k$ is the probability of occurrence of stress $i\left(\mathrm{~T}+5^{\circ} \mathrm{C}, \mathrm{T}>30^{\circ} \mathrm{C}, \mathrm{R} 50 \%, \mathrm{~T}+5^{\circ} \mathrm{C}\right.$ plus $\mathrm{R} 50 \%, \mathrm{~T}>30^{\circ} \mathrm{C}$ plus R50\%) on day $j, x$ is the number of times with stress $i$ for day $j$ in the climatic series of site $k, n$ is the number of years of the climatic series of site $k$.

The monthly probability of occurrence was calculated through the average of the daily values corresponding to the month. The monthly probability of occurrence of the combined events of high temperature and cloudiness $\left(T>30^{\circ} \mathrm{C}\right.$ plus $\mathrm{R} 50 \%$; $T+5^{\circ} \mathrm{C}$ plus $\mathrm{R} 50 \%$ ) from September to December is shown in maps of the Southern Cone of South America in Figures 3 and 4.

The cumulative probability of each event was calculated as the sum of the daily probability of the event from September $1^{\text {st }}$. The cumulative probability during the post-flowering period was calculated for each location, as the difference between the cumulative probability for $\mathrm{PM}$ and the cumulative probability for $\mathrm{F}$ (Table 2). The time-course of the cumulative probability of $\mathrm{T}>30^{\circ} \mathrm{C}, \mathrm{T}+5^{\circ} \mathrm{C}$ and R50\% events was represented only for selected representative locations in each area from September $1^{\text {st }}$ to December $31^{\text {st }}($ Fig. 2$)$. The meaning of the value of this variable indicates how likely the combined event is to take place on and before a certain date. For example, a $60 \%$ cumulative probability in PM means that there was a $60 \%$ probability the event occurred in PM or prior to that date, or in other words, there was a $40 \%$ probability that the event did not take place in the period.

Graphs for the probabilities of occurrence of individual events (Fig. 2) and for the cumulative probability of the combined events (Fig. 7) are shown in some representative locations of each country and of each area in order to facilitate the presentation of the results. 
Selected locations were Passo Fundo (Brazil) and Reconquista (Argentina) representing the northern area, Salto Grande (Uruguay) for the central area and Tres Arroyos (Argentina) and Pichoy (Chile) for the southern area.

Graphs of the time-course of high temperature and cloudiness events over the last 28 years, sorted by each area, are attached to this work as supplementary material (Supplementary Figs. S2 to S10), detailing the probability values of occurrence of these events for each location along the period 1990 to 2018 (series of years in common for all locations). This value was calculated annually for each location by averaging the monthly probabilities of occurrence for September, October, November and December.

\section{Results}

\subsection{Probability of heat stress events}

The probabilities of maximum daily temperature $>30^{\circ} \mathrm{C}\left(\mathrm{T}>30^{\circ} \mathrm{C}\right)$ and of $5^{\circ} \mathrm{C}$ above the historical average $\left(\mathrm{T}+5^{\circ} \mathrm{C}\right)$ were analysed for the evaluated 33 locations (Supplementary Table S1). Data of representative locations in each area are shown in Figure 2. Daily probabilities of both types of heat stress events differed in their trends in each locality from September $1^{\text {st }}$ to December $31^{\text {st }}$. When heat events of $\mathrm{T}>30^{\circ} \mathrm{C}$ were assessed, the daily probability of its occurrence was increasing after $\mathrm{F}$ in most of these locations (Fig. 2 left). Salto Grande showed the highest average probability $(26 \%)$ of $\mathrm{T}>30^{\circ} \mathrm{C}$ during the post-flowering period, followed by Reconquista, Tres Arroyos (25\% in both locations) and Passo Fundo (11\%). On the contrary, the lowest probability was recorded in Pichoy, where the probability was almost zero during the post-flowering period.

The heat stress event $\mathrm{T}+5^{\circ} \mathrm{C}$ did not show a clear trend for the post-flowering period of wheat and canola. However, a slight decline towards PM was found in low latitude locations such as Passo Fundo, Reconquista and Salto Grande. In these locations, the daily probability of $\mathrm{T}+5^{\circ} \mathrm{C}$ event was close to or lower than $20 \%$ (Fig. 2, central panels). In other words, maximum daily temperature was over the historical daily maximum temperature by $5^{\circ} \mathrm{C}$ every $\sim 2$ out of 10 years. This daily probability was similar along the postflowering period. Across the evaluated locations, the average probability of $\mathrm{T}+5^{\circ} \mathrm{C}$ during the post-flowering period ranged from 10 to $16 \%$.

Additionally, the typical duration of the post-flowering period for each of the 33 locations and the probabilities of occurrence of $\mathrm{T}>30^{\circ} \mathrm{C}$ and $\mathrm{T}+5^{\circ} \mathrm{C}$ events were represented graphically (Supplementary Fig S1).

\subsection{Probability of cloudiness events}

Cloudiness events decreasing global solar radiation by $50 \%$ relative to historical data (R50\%) from $\mathrm{F}$ to MF showed higher daily probability at the beginning of the post-flowering period (Fig. 2, right panels). Across areas and locations of the Southern Cone, clear differences were found in cloudiness patterns. In the northern and central areas, the daily probability ranged from 10 to $60 \%$ throughout the post-flowering period. A lower daily probability was observed in the southern area, with daily probability ranging $3 \%$ to $30 \%$. When comparing the average probability for post-flowering, Passo Fundo showed the highest value (38\%) followed by Reconquista, Salto Grande and Tres Arroyos (23\%), while the lowest was found in Pichoy (10\%) (Fig. 2, right panels).

Similar to $\mathrm{T}>30^{\circ} \mathrm{C}$ and $\mathrm{T}+5^{\circ} \mathrm{C}$ events, the average probability of daily occurrence of R50\% for each location during the typical duration of the post-flowering period is shown in Supplementary Figure S1.

\subsection{Time-course of high temperature and cloudiness events}

The time-course of the probability of $\mathrm{T}>30^{\circ} \mathrm{C}$ and $\mathrm{T}+5^{\circ} \mathrm{C}$ events has been increasing in some locations and has remained stable in others over the last 28 years (Supplementary Figs. S2 to S7). Example of locations with a tendency to increase the probability of $\mathrm{T}>30^{\circ} \mathrm{C}$ events over the years were Ceres, Salta, Laboulaye, Rio Cuarto, Trenque Lauquen, Santa Rosa, General Pico and Bolivar (Figs. S2 to S4). Other locations as Santiago del Estero, Sauce Grande and Bahía Blanca showed stability for this event, while it did not occur in Pichoy and Chillán. For the $T+5^{\circ} \mathrm{C}$ event, locations such as Salta, Bahía Blanca, General Pico, Coronel Suárez, Mar del Plata, Trenque Lauquen, Santa Rosa, Bolivar and Tres Arroyos increased the probability of occurrence of high temperatures since 2001, while Guarapuava, Gualeguaychú and Pichoy remained stable throughout the last 28 years (Figs. S5 to S7).

The probability of R50\% event has been variable according to each area (Supplementary Figs. S8 to S10). In the northern area, it is worth noting the increase in the incidence of R50\% in Guarapuava and Santiago del Estero since approximately 2010. Also, since this year, certain increases in the probability of occurrence of R50\% have also been observed in some locations of the central area, such as 
Gualeguaychú, Venado Tuerto, Sauce Viejo, Rosario, and Salto Grande. Regarding the southern area, locations such as Olavarría, Bolivar, Coronel Suárez, Junín, and Santa Rosa tended to lower the probability of R50\% until 2010 and then it seems to increase slightly. A separate case in this area was Trenque Lauquen, which increased its probability until 2001 and subsequently decreased (Supplementary Fig. S10).

\section{- Probabilities of occurrence of combined events of high temperature and cloudiness}

For $\mathrm{T}>30^{\circ} \mathrm{C}$ plus $\mathrm{R} 50 \%$ combined event (Fig. 3), the monthly probability of occurrence varied in both temporal and spatial scale. In the sites located in the north-northwest of the Southern Cone of South America the $\mathrm{T}>30^{\circ} \mathrm{C}$ plus R $50 \%$ event was already evident in September, and in the central and southern sites, it was only clear from October onward. The monthly probability of this event increased from September to December across locations, largely explained by the increase in maximum temperature from the end of spring.

Within each area (north, central, south) the monthly probability of occurrence of the event presented variability among locations. In the northern area, during the post-flowering period of wheat and canola (September-October), monthly probabilities of combined stress ( $\mathrm{T}>30^{\circ} \mathrm{C}$ plus R50) were from $<10 \%$ in those locations of greater elevation (e.g., Guarapuava, $1120 \mathrm{~m}$ of altitude) to probabilities ranging 61 to $70 \%$ at lower altitudes (e.g., Londrina, $650 \mathrm{~m}$ and Santiago del Estero, $200 \mathrm{~m}$ ).

In the central area, the post-flowering period took place from October to November. In that period, monthly probabilities of occurrence of $\mathrm{T}>30^{\circ} \mathrm{C}$ plus R $50 \%$ events also varied among locations, from $<10 \%$ in La Estanzuela to the highest values in Venado Tuerto, ranging $41-50 \%$, while in the rest of locations probability ranged between 21 and $40 \%$ (Fig. 3).

For the southern area, the highest monthly probability of $\mathrm{T}>30^{\circ} \mathrm{C}$ plus $\mathrm{R} 50 \%$ events during the post-flowering period was found from November to December in Trenque Lauquen, with maximum monthly probabilities from 71 to $80 \%$. In Santa Rosa, Tandil, Coronel Suárez, and Tres Arroyos, probability ranged between 21 and $30 \%$, while the lowest probability for combined stress $\mathrm{T}>30^{\circ} \mathrm{C}$ plus R50\% was observed in the Chilean locations of Chillán and Pichoy $(<10 \%)$.

The $\mathrm{T}+5^{\circ} \mathrm{C}$ plus R50\% combined events presented the highest monthly probability in the south-southeastern locations of the region, especially during September, which is prior to the occurrence of post-flowering in those locations (Fig. 4). Towards October and November, the monthly probability of the events declined from the north to the south areas, while in December the probabilities of occurrence decreased in the great majority of the locations of the Southern Cone, with the exception of General Pico, Olavarría and Mar del Plata (in the southern area). Despite the general trend described above, the magnitude of the monthly probability of occurrence of $\mathrm{T}+5^{\circ} \mathrm{C}$ plus R50\% varied between locations of each area. Salta and Passo Fundo (both from the north area) as well as Río Cuarto and Tacuarembó (both from the central area) exhibited the highest monthly probabilities of the $T+5^{\circ} \mathrm{C}$ plus R $50 \%$ combined events during post-flowering, reaching values close to $40 \%$. For the rest of locations, such probability was below $30 \%$ (Fig. 4). For the southern area, Mar del Plata and General Pico stood out from the rest, with a mean monthly probability of $56 \%$ and $46 \%$, respectively.

Regarding the number of days per month under a combined event (Figs. 3 and 4), an association was observed between the magnitude of the calculated probability values of $\mathrm{T}>30^{\circ} \mathrm{C}$ plus $\mathrm{R} 50 \%$ and $\mathrm{T}+5^{\circ} \mathrm{C}$ plus R50\% events for each month (colour scale) and the number of days when it took place within each month (point size). In other words, probabilities below $30 \%$ in the months of September to December were associated with very low frequencies of days of occurrence per month (less than 0.5 days in a month); probabilities between 31 and $50 \%$ were related to frequencies of occurrence of 0.5 to 1 day per month and the highest probabilities, between 51 to $80 \%$, with the highest frequencies of occurrence of days per month, with values from 1 to 4 days per month. When the probability of occurrence was related to the number of days of stress per month (Figs. 5 and 6), an asymptotic curve was observed for both combined stress events but differing among monthly periods. Thus, for the $\mathrm{T}>30^{\circ} \mathrm{C}$ plus $\mathrm{R} 50 \%$ event the relationship was more noticeable in November and December with no different trends between locations per area (north, central, south). In the $\mathrm{T}+5^{\circ} \mathrm{C}$ plus R50\% event the relationship was stronger in September where it was observed that the locations of the southern area presented the highest probabilities and the largest number of days.

\subsection{Cumulative probability during post-flowering period}

Cumulative probabilities of occurrence of both combined stress events, throughout the post-flowering period typical for each area were calculated for all locations (Table 2). In addition, cumulative probability (cumulated from the 1st September) of occurrence of both 
types of combined events $\mathrm{T}>30^{\circ} \mathrm{C}$ plus $\mathrm{R} 50 \%$ and $\mathrm{T}+5^{\circ} \mathrm{C}$ plus $\mathrm{R} 50 \%$, are compared for selected locations from each area: Passo Fundo and Reconquista for the northern area, Salto Grande for the central area, and Tres Arroyos for the southern area (Fig. 7).

In Passo Fundo, the $\mathrm{T}>30^{\circ} \mathrm{C}$ plus R50\% event presented a high cumulative probability (from the $1^{\text {st }}$ September) during the period between $\mathrm{F}$ and $\mathrm{PM}$, with $19 \%$ in $\mathrm{F}$ and $48 \%$ in $\mathrm{PM}$, which indicated a cumulative probability of $29 \%$ for the post-flowering period (Fig. 7 left and Table 2). Thus, in $\sim 3$ out of 10 years, the $T>30^{\circ} \mathrm{C}$ plus R50 combined event occurred during the typical post-flowering period in this northern location. A slightly higher value of cumulative probability for the $T+5^{\circ} \mathrm{C}$ plus $\mathrm{R} 50 \%$ event during post-flowering, around $38 \%$ was found in Passo Fundo, which was the highest cumulated value obtained compared to the rest of the sites in the northern area (Table 2). By contrast, in Reconquista the cumulated probability during the post-flowering period was higher for $\mathrm{T}>30^{\circ} \mathrm{C}$ plus $\mathrm{R} 50 \%$ (43\%) compared to $\mathrm{T}+5^{\circ} \mathrm{C}$ plus R50\% (26\%; Table 2).

Finally, Salto Grande and Tres Arroyos showed similar cumulated values in PM, with $44-40 \%$ for $\mathrm{T}>30^{\circ} \mathrm{C}$ plus $\mathrm{R} 50 \%$, and $72-74 \%$ for $\mathrm{T}+5^{\circ} \mathrm{C}$ plus R50\%, respectively (Fig. 7). During the post-flowering period, the cumulated probability was similar at both sites, with around $40 \%$ for $\mathrm{T}>30^{\circ} \mathrm{C}$ plus $\mathrm{R} 50 \%$, and around $20 \%$ for $\mathrm{T}+5^{\circ} \mathrm{C}$ plus R50\% event (Table 2 ).

Comparing (across locations) the average cumulative probability during post-flowering period was $42 \%$ in the $\mathrm{T}>30^{\circ} \mathrm{C}$ plus R $50 \%$ event vs. $15 \%$ in the $\mathrm{T}+5^{\circ} \mathrm{C}$ plus R50\% event for the northern area; whereas it was $26 \%$ vs $19 \%$ in the central area, and $28 \%$ vs $1 \%$ in the southern area, respectively (Table 2). It is worth noting that only for Pichoy and Chillán, in the southernmost area at the west of the Andes, there were no increases of cumulative probability of any combined stress events during the post-flowering period (Table 2).

\section{Discussion}

This study aimed at quantifying the occurrence of events of high maximum temperatures and cloudiness during the post-flowering period of temperate crops in the Southern Cone of South America during the last three to five decades. The heat stress event was defined by two indicators: i) maximum daily temperature exceeding a thermal threshold $\left(T>30^{\circ} \mathrm{C}\right)$, and ii) temperature $5^{\circ} \mathrm{C}$ above the maximum historical average of that day $\left(\mathrm{T}+5^{\circ} \mathrm{C}\right)$. The choice of both heat stresses is supported by experimental evidence on their differential physiological effects on grain yield and quality of wheat and canola during grain filling (Aksouh et al., 2001; Sial et al., 2005; Yin et al., 2009; Wu et al., 2020). Also, attempts have been made to incorporate responses to both types of heat stress events to simulation crop models around the world, although more work needs to be done in this respect (Asseng et al., 2015; Lilley et al., 2015; Liu et al., 2016; Qian et al., 2018; Hussain et al., 2018; Liu et al., 2020).

Contrary to expectations, the occurrence of both heat stresses was different along latitude and over time from September to December. Therefore, the occurrence of both heat stresses did not show association. Most of the 33 evaluated locations in the Southern Cone of South America (from $23^{\circ} \mathrm{S}$ to $40^{\circ} \mathrm{S}$ ) showed that the lower the latitude, the higher the $\mathrm{T}>30^{\circ} \mathrm{C}$, in accordance with Linacre and Geerts (1997) and Jimenez and Oliver (2005). Also, $\mathrm{T}>30^{\circ} \mathrm{C}$ increased from September to December. Thus, maximum daily temperatures above $30^{\circ} \mathrm{C}$ have been the most frequent heat stress during post-flowering of temperate crops in most locations in the Southern Cone, with locations at low latitude and delayed post-flowering being the riskiest. One exception was observed, as Pichoy (in southern Chile) did not virtually present any risk of $\mathrm{T}>30^{\circ} \mathrm{C}$, associated with a cold Mediterranean climate characteristic of this pre-Andean area, with average maximum temperature during post-flowering period of $20.4^{\circ} \mathrm{C}$, significantly distant from $30^{\circ} \mathrm{C}$.

The $\mathrm{T}+5^{\circ} \mathrm{C}$ event quantified maximum daily temperature exceeding the historical average value of a given day by $5^{\circ} \mathrm{C}$. For this event to occur, there must be variability in temperature, which is evidenced in the so-called mid-latitudes "between 30 and $60^{\circ} \mathrm{S}$ ", where the strong westerly wind belt generates a much greater thermal variability (Jimenez and Oliver, 2005). Over the southern tip of South America and the adjacent South Pacific, the west winds are stronger toward the austral summer, peaking between 45 and $55^{\circ} \mathrm{S}$ (Garreaud et al., 2009). The occurrence of $\mathrm{T}+5^{\circ} \mathrm{C}$ event during the post-flowering period turned out to be an indicator of high temperatures less likely to occur and exhibited a different behaviour compared to the $T>30^{\circ} \mathrm{C}$ event. The results indicated no trend or a slight decrease in $\mathrm{T}+5^{\circ} \mathrm{C}$ probability throughout the post-flowering in most locations. Thus, $\mathrm{T}+5^{\circ} \mathrm{C}$ stress is more susceptible to be found for early September in locations at mid-latitudes in the Southern Cone.

Vincent et al. (2005) examined the trends of extreme daytime and nighttime temperatures during the period 1960-2000, covering several countries from South America. Their results indicated significant trends in the daily minimum temperature, but no consistent changes in the indices based on daily maximum temperature, concluding that the warming was mainly due to the increase in warm nights during summer and winter. In line with the asymmetric warming described by Vincent et al. (2005), García et al. (2018) modelled 
yield and phenology of wheat and barley crops using APSIM with historical climate series (1961-2014) for representative sites of the Pampas and observed a positive trend for average mean temperature during the September, October and November season (from 0.02 to $0.49^{\circ} \mathrm{C}$ decade $\left.^{-1}\right)$. At a regional scale, changes in mean temperature during that period were better explained by variation in minimum rather than maximum temperature (García et al., 2018). Those increases in the minimum temperature reduced the flowering time, by shortening the duration of the critical period (on average $0.6 \mathrm{~d}$ decade- 1 ), and decreased the yield between ca. 2 and $9 \%$ per ${ }^{\circ} \mathrm{C}$ across the Pampas locations, as a consequence of less accumulated radiation capture and less incident radiation, due to the winter shift. More recently, Feron et al. (2019) found that the frequency of days exceeding the $95^{\text {th }}$ percentile of the maximum temperatures increased at less 3 days per season during the summer (December-January-February) towards lower latitudes. A value of 3 days of very high daily temperature $\left(T>30^{\circ} \mathrm{C}\right)$ is quite frequent even during the spring (September-October-November) for temperate crops, as observed in the present work.

Cloudiness, defined here as a $50 \%$ reduction in daily incident solar radiation (R50\%) during post-flowering, was higher in the northernmost locations (from southern Brazil and northern Argentina). Several studies have reported trends of incident solar radiation around the world in the last decades (Abakumova et al., 1996; Stanhill and Cohen, 2001; Liepert, 2002) with a general decreasing trend from 1950 to 1980, mainly due to variations in cloud cover, followed by an increase since 1980, largely associated with changes in air pollution levels (Wild, 2009). The causes of variations in cloud cover were not analysed in our work because the global solar radiation data of each location was estimated through the data of sunshine duration. Raichijk (2011) analysed the duration of insolation in 6 countries of South America (Argentina, Bolivia, Brazil, Paraguay, Peru and Uruguay), and a decreasing trend was observed from 1961 to 1990 , changing to an increase from 1991 to 2004. In our work, the dynamics of the R50\% event during 1990-2018 differed among locations, even in those very close and located at the same latitude. For several locations it was a tendency to increase the probability of R50\% since 2010. But no trend was observed in other locations from Argentina and Chile, and only in Trenque Lauquen a decreasing trend was observed since 2000 (Supplementary Fig. S10). The causes of the differences in cloudiness trends between locations deserve to be further studied, as related to typical patterns of cloud cover, pollution and rain in the Southern Cone of South America.

To the best of our knowledge, this is the first report that assesses the occurrence of combined events of high maximum temperatures and cloudiness during the post-flowering of temperate crops of the Southern Cone. For both combined events, the thermal effect dominated over the cloudiness in most locations. The main difference between $\mathrm{T}>30^{\circ} \mathrm{C}$ plus $\mathrm{R} 50 \%$ and $\mathrm{T}+5^{\circ} \mathrm{C}$ plus R $50 \%$ events was found in the month in which both events reached their highest probability of risk (Figs. 3 and 4). In the vast majority of locations, the combined $\mathrm{T}>30^{\circ} \mathrm{C}$ plus R50\% event had its greatest impact during December, contrary to the greatest occurrence in September for the $\mathrm{T}+5^{\circ} \mathrm{C}$ plus R50\% event. Also, a positive curvilinear relationship emerged between the probability of combined stresses and the number of days with stress per month, for all locations in South America (Figs. 5 and 6). Thus, combined stresses are not isolated events, and the higher the risk of combined stress, the greater the probability of suffering it for several days. This is relevant, as a certain number of days of exposure to stress is required to irreversibly affect crop yield (Wardlaw et al., 2002; Rondanini et al., 2006).

Regarding the probabilities of occurrence of thermal and cloudiness combined stresses, the northernmost area may escape the $\mathrm{T}>30^{\circ} \mathrm{C}$ plus R50\%, as the grain-filling period of wheat and canola ends by December. This combined stress is potentially harmful for the central and southern areas, since it coincides with the effective gran-filling and flowering period, respectively. On the other hand, the occurrence of $\mathrm{T}+5^{\circ} \mathrm{C}$ plus R50\% mainly in September coincides with flowering in the northernmost region, whereas central and southern areas do not compromise their critical period as crops are usually in the pre-flowering stage. Overlapping Figs. 3 and 4, it is clear that the southernmost area is likely to be affected by both types of combined stresses during December, coinciding with the grain-filling period of wheat and canola. Currently, there is no bibliographic information on the consequences of simultaneous high temperature and light stress on the yield in wheat and canola during the grain-filling period.

\section{Conclusion}

In the last 3-5 decades in the Southern Cone of South America, temperate crops have faced the risk of thermal, cloudiness, and both combined stresses during the post-flowering period. The probability of thermal stress $\mathrm{T}>30^{\circ} \mathrm{C}$ during grain filling was higher than $\mathrm{T}+5^{\circ} \mathrm{C}$. Dynamics of cloudiness events exhibited diverse trends over the years, and thermal stress drives the probability of combined stresses. The monthly probability of combined stresses and the number of days with stress per month showed a positive curvilinear association. The south area (except for Pichoy and Chillán, in the south area at the west of the Andes) is likely to be affected by both types of combined stresses during December, when the grain-filling period in wheat and canola crops occurs. This study evidences the 
recent past and current occurrence of heat stress individually and combined with cloudiness events during post-flowering of temperate crops, serving as a baseline for future climate scenarios in main cropped areas in the Southern Cone of South America.

\section{Declarations}

Acknowledgments The meteorological information was provided by the National Meteorological Service (SMN, Argentina), National Institute of Agricultural Research (INIA, Uruguay), Institute of Agricultural Research (INIA, Chile) and Paraná Agronomic Institute (IAPAR, Brazil). We thank Leandro Cobacho, Pablo Nitsche, Patrico Sandaña, and Christian Bredemeier for facilitating data collection.

\section{Conflict of Interest}

Funding information This research was supported by grants from the National Agency of Promotion of Science and Technology (PICT 2016-1294), and the Education Ministry of Argentina (VT42-UNLZ12219).

\section{Non-financial interests: none}

Availability of data and material: The meteorological information was provided by the National Meteorological Service (SMN, Argentina), National Institute of Agricultural Research (INIA, Uruguay), Institute of Agricultural Research (INIA, Chile) and Paraná Agronomic Institute (IAPAR, Brazil).

\section{Code availability: not applicable}

\section{Author's Contribution}

D Rondanini and G Abeledo contributed to the study conception and design. Material preparation, data collection and analysis were performed by G Rivelli and ME Fernandez Long. The first draft of the manuscript was written by G Rivelli and all authors commented on previous versions of the manuscript. All authors read and approved the final manuscript.

\section{References}

1. Abakumova GM, Feigelson EM, Bussak V, Stadnik VV (1996) Evaluation of long-term changes in radiation, cloudiness and surface temperature on the territory of the former Soviet Union. J Climate 9: 1319-1327. https://doi.org/10.1175/15200442(1996)009<1319: EOLTCl>2.0.C0;2

2. Aksouh NM, Jacobs BC, Stoddard FL, Mailer RJ (2001) Response of canola to different heat stress. Aust J Agric Res 52: 817-824. https://doi.org/10.1071/AR00120

3. Aksouh NM, Campbell LC, Mailer RJ (2006) Canola response to high and moderately high temperature stresses during seed maturation. Can J Plant Sci 86: 967-980. https://doi.org/10.4141/P05-130

4. Aksoy B (1997) Variations and trends in global solar radiation for Turkey, Theor Appl Climatol 58: 71-77. https://doi.org/10.1007/BF00867433

5. Angström A (1924) Solar terrestrial radiation. Q. J. R. Meteorol Soc 50: 121-126. https://doi.org/10.1002/qj.49705021008

6. Asseng S, Ewert F, Martre P, et al (2015) Rising temperatures reduce global wheat production. Nature Clim Change 5: 143-147. https://doi.org/10.1038/nclimate2470

7. Asseng S, Kassie BT, Labra MH, Amador C, Calderini DF (2017) Simulating the impact of source-sink manipulations in wheat. Field Crops Res 202: 47-56. https://doi.org/10.1016/j.fcr.2016.04.031

8. Atlantica Sementes. Catálogos de canola disponibles en: http://www.atlanticasementes.com.br/produtos/canola/canola-nuola$300 /$

9. Barros VR, Boninsegna JA, Camilloni IA, Chidiak M, Magrín GO, Rusticucci M (2015) Climate change in Argentina: Trends, projections, impacts and adaptation. Wiley Interdisciplinary Reviews: Clim Change 6:151-169. https://doi.org/10.1002/wcc.316 
10. Barry RG, Chorley RJ (2003) Atmosphere Weather \& Climate. Routledge editor (Eighth edition). London and New York. $421 \mathrm{p}$

11. Bartoszek K, Matuszkob D, Sorokac J (2020) Relationships between cloudiness, aerosol optical thickness, and sunshine duration in Poland. Atmos Res 245: 105097. https://doi.org/10.1016/j.atmosres.2020.105097

12. Brocklehurst PA, Moss JP, Williams W (1978) Effects of irradiance and water supply on grain development in wheat. Ann Appl Biol 90: 265-276. https://doi.org/10.1111/j.1744-7348.1978.tb02635.x

13. Diepenbrock W (2000) Yields analysis of winter oilseed rape (Brassica napus): a review. Field Crops Res 67: 35-49. https://doi.org/10.1016/S0378-4290(00)00082-4

14. Evans LT (1978) The influence of irradiance before and after anthesis on grain yield and its components in microcrops of wheat grown in a constant daylength and temperature regime. Field Crops Research 1: 5-19. https://doi.org/10.1016/03784290(78)90003-5

15. FAO (2015) Climate change and food systems: global assessments and implications for food security and trade. Food Agriculture Organization of the United Nations (FAO) http://www.fao.org/3/a-i4332e.pdf last accessed December 122020

16. FAO (2020) FAOSTAT http://www.fao.org/faostat/es/\#data last accessed December 192020

17. Feron S, Cordero RR, Damiani A, Llanillo PJ, Jorquera J, Sepulveda E, Asencio V, Laroze D, Labbe F, Carrasco J, Torres G (2019) Observations and Projections of Heat Waves in South America. Sci Rep 9: 8173. https://doi.org/10.1038/s41598-019-44614-4

18. Fischer RA (1985) Number of kernels in wheat crops and the influence of solar radiation and temperature. J Agric Sci 105: 447461. https://doi.org/10.1017/S0021859600056495

19. Fischer RA (2007) Understanding the physiological basis of yield potential in wheat. J Agric Sci 145: 99-113. https://doi.org/10.1017/S0021859607006843

20. García GA, Miralles DJ, Serrago RA, Alzueta I, Huth N, Dreccer MF (2018) Warm nights in the Argentine Pampas: modelling its impact on wheat and barley yield shows yield reductions. Agric Syst 162: 259-268. https://doi.org/10.1016/j.agsy.2017.12.009

21. Garreaud RD, Vuille M, Compagnucci R, Marengo J (2009) Present-day South American climate. Paleogeogr Paleoclimatol Paleoecol 281: 180-195. https://doi.org/10.1016/j.palaeo.2007.10.032

22. Gazzano I, Achkar M, Diaz I (2019) Agricultural Transformations in the Southern Cone of Latin America: Agricultural Intensification and Decrease of the Aboveground Net Primary Production, Uruguay's Case. Sustainability 11: 7011.

https://doi.org/10.3390/su11247011

23. Gilgen $H$, Wild M, Ohmura A (1998) Means and trends of shortwave irradiance at the surface estimated from Global Energy Balance Archive Data. J Climate 11: 2042-2061. https://doi.org/10.1175/1520-0442(1998)011<2042:MATOSI>2.0.CO;2

24. Hussain J, Khaliq T, Ahmad A, Akhtar J (2018) Performance of four crop model for simulations of wheat phenology, leaf growth, biomass and yield across planting dates. PLoS ONE 13: e0197546. https://doi.org/10.1371/journal.pone.0197546

25. Iglesias FM, Miralles DJ, (2014) Changes in seed weight in response to different sources: sink ratio in oilseed rape. Int J Agril Res Innov \& Tech 4: 44-52. https://doi.org/10.3329/ijarit.v4i1.21091

26. INIA (Instituto de investigaciones agropecuarias). Available on: http://www.inia.org.uy/convenio_inase_inia/Evaluacion_Cl/Ano2017/PubTrigoLargoPeriodo2017_FINAL.pdf last accessed December 22020

27. IPCC (2013) "Resumen para responsables de políticas. En: Cambio Climático 2013: Bases físicas. Contribución del Grupo de trabajo I al Quinto Informe de Evaluación del Grupo Intergubernamental de Expertos sobre el Cambio Climático" [Stocker, T. F., D. Qin, G.-K. Plattner, M. Tignor, S. K.Allen,J Boschung, A. Nauels, Y. Xia, V. Bex y P.M. Midgley (eds.)]. Cambridge University Press, Cambridge, Reino Unido y Nueva York, NY, Estados Unidos de América. 
28. IPCC (2018) Global warming of $1.5^{\circ} \mathrm{C}$. Special Report, Intergovernmental Panel on Climate Change James Retal (2017) Characterizing half-a-degree difference: a review of methods for identifying regional climate responses to global warming. WIREs Clim Change 8:e45

29. Jimenez N, Oliver JE (2005) South America, Climate of. In: Oliver J.E. (eds) Encyclopedia of World Climatology. Encyclopedia of Earth Sciences Series. Springer, Dordrecht

30. Kirkegaard JA, Lilleya JM, Brillb RD, Warec AH, Walela CK (2018) The critical period for yield and quality determination in canola (Brassica napus L.) Field Crops Res 222:180-188. https://doi.org/10.1016/j.fcr.2018.03.018

31. Labra M, Struik PC, Evers JB, Calderini DF (2017) Plasticity of seed weight compensates reductions in seed number of oilseed rape in response to shading at flowering. Europ J Agron 84:113-124. https://doi.org/10.1016/j.eja.2016.12.011

32. Liepert BG (2002) Observed reductions of surface solar radiation at sites in the United States and worldwide from 1961 to 1990. Geophys Res Lett 29:1421. https://doi.org/10.1029/2002GL014910

33. Linacre E, Geerts B (1997) Climates and weather explained: An Introduction from Southern Perspective. Routledge editor (First edition). Lincoln, United Kingdom. $464 \mathrm{p}$

34. Lilley JM, Bell LW, Kirkegaard JA (2015) Optimising grain yield and grazing potential of crops across Australia's high-rainfall zone: a simulation analysis. 2. Canola. Crop Pasture Sci 66: 349-364. https://doi.org/10.1071/CP14240

35. Lilley JM, Flohr BM, Whish JPM, Farre I, Kirkegaard JA (2019) Defining optimal sowing and flowering periods for canola in Australia. Field Crops Res 235: 118-128. https://doi.org/10.1071/CP20226

36. Liu B, Asseng S, Liu L, Tang L, Cao W, Zhu Y (2016) Testing the responses of four wheat crop models to heat stress at anthesis and grain filling. Glob Change Biol 22: 1890-1903. https://doi.org/10.1111/gcb.13212

37. Liu B, Liu L, Asseng S, Zhang D, Ma W, Tang L, Cao W, Zhu Y (2020) Modelling the effects of post-heading heat stress on biomass partitioning, and grain number and weight of wheat. J Exp Bot 71:6015-6031. https://doi.org/10.1093/jxb/eraa310

38. Lizana XC, Calderini DF (2013) Yield and grain quality of wheat in response to increased temperatures at key periods for grain number and grain weight determination: considerations for the climatic change scenarios of Chile. J Agric Sci 151: 209-221. https://doi.org/10.1017/S0021859612000639

39. Marengo J, Chou SC, Torres R, Giarolla A, Alves L, Lyra A (2014) Climate Change in Central and South America: Recent Trends, Future Projections, and Impacts on Regional Agriculture. CCAFS Working Paper no. 73. CGIAR Research Program on Climate Change, Agriculture and Food Security (CCAFS). Copenhagen, Denmark

40. Matuszko D, Stanisław W (2015) Relationship between sunshine duration and air temperature. Int J Climatol 3653: 3640-3653. https://doi.org/10.1002/joc.4238

41. Mera M, Lizana CX, Calderini DF (2015) Chapter 6: Cropping systems in environments with high yield potential of southern Chile. In: Crop Physiology (Second Edition), Sadras VO and Calderini DF (Eds). 111-140 p. Academic Press, New York.

42. Miralles DJ, González FG, Abeledo LG, Serrago RA, Alzueta I, García GA, de San Caledonio RP, Lo Valvo PJ (2014) Manual de trigo y cebada para el Cono Sur. Procesos fisiológicos y bases de manejo. 1a ed., Orientación Gráfica Editora, Buenos Aires, Argentina

43. Norris J R, Wild M (2007) Trends in aerosol radiative efects over Europe inferred from observed cloud cover, solar 'dimming', and solar 'brightening'. J Geophys Res 112: D08214. https://doi.org/10.1029/2006JD007794

44. Omran MA (2000) Analysis of solar radiation over Egypt. Theor Appl Climatol 67: 225-240. https://doi.org/10.1007/s007040070011

45. Pan D, Graneri J, Bettucci L (2009) Correlation of rainfall and levels of deoxynivalenol in wheat from Uruguay, 1997-2003. Food Additives and Contaminants 2: 162-165. https://doi.org/10.1080/02652030903213886

Page $11 / 24$ 
46. Pengue WA (2015) Dinámicas y perspectivas de la agricultura actual en latinoamérica. Bolivia, Argentina, Paraguay y Uruguay. In collaboration with Andrea Rodríguez and Elba Stanich. Fundación Heinrich Böll Cono Sur. 213 p

47. Power HC, Mills DM (2005) Solar radiation climate change over South Africa and an assessment of the radiative impact of volcanic eruptions. Int J Climatol 25: 295-318. https://doi.org/10.1002/joc.1134

48. Qian B, Jing Q, Bélanger G, Shang J, Huffman T, Liu J, Hoogenboom G (2018) Simulated canola yield responses to climate change and adaptation in Canada. Agron J 110:133-146. https://doi.org/10.2134/agronj2017.02.0076

49. Raichijk C (2011) Observed trends in sunshine duration over South America. Int J Climatol 32: 669-680. https://doi.org/10.1002/joc.2296

50. Reed WW (1929) Monthly weather review climatological: data for southern South America. Supplement No. 32. U.S. Government Printing Office Editor. United States, Washington D.C. 23p

51. Ren GY, Guo J, Xu MZ (2005) Climate changes of China's mainland over the past half century. Acta Meteorol Sin 63: $942-956$. https://doi.org/10.3354/cr01067

52. Rondanini D, Mantese A, Savin R, Hall AJ (2006) Responses of sunflower yield and grain quality to alternating day/night high temperature regimes during grain filling: Effects of timing, duration and intensity of exposure to stress. Field Crops Res 96: 48-62. https://doi.org/10.1016/j.fcr.2005.05.006

53. Russak V (1990) Trends of solar radiation, cloudiness and atmospheric transparency during recent decades in Estonia. Tellus Ser B 42: 206:210. https://doi.org/10.1034/j.1600-0889.1990.t01-1-00006.x

54. Rusticucci M, Renom M (2007) Variability and trends in indices of quality-controlled daily temperature extremes in Uruguay. Int $J$ Climatol 28: 1083-1095. https://doi.org/10.1002/joc.1607

55. Savin R, Slafer GA (1991) Shading effects on the yield of an Argentinian wheat cultivar. J Agric Sci 116, 1-7. https://doi.org/10.1017/S0021859600076085

56. Serrago RA, Alzueta I, Savin R, Slafer GA (2013) Understanding grain yield responses to source-sink ratios during grain filling in wheat and barley under contrasting environments. Field Crops Res 150: 42-51. https://doi.org/10.1016/j.fcr.2013.05.016

57. Sial MA, Arain MA, Khanzada Shamadad, Naqvi MH, Dahot MU, Nizamani NA (2005) Yield and quality parameters of wheat genotypes as affected by sowing dates and high temperature stress. Pak J Bot 37:575. http://www.pakbs.org/pjbot/PDFs/37(3)/PJB37(3)575.pdf

58. Sillmann J, Kharin VV, Zwiers FW, Zhang X, Bronaugh D (2013) Climate extremes indices in the CMIP5 multimodel ensemble: Part 2. Future climate projections, J Geophys Res Atmos 118: 2473- 2493. https://doi.org/10.1002/jgrd.50188

59. Stanhill G, Cohen S (2001) Global dimming: a review of the evidence for a widespread and significant reduction in global radiation with discussion of its probable causes and possible agricultural consequences. Agric For Meteorol 107: 255-278. https://doi.org/10.1016/S0168-1923(00)00241-0

60. Tahir ISA, Nakata N, Ali A M, Mustafa HM, Saad ASI, Takata K, Ishikawa N, Abadia OS (2006) Genotypic and temperature effects on wheat grain yield and quality in a hot irrigated environment. Plant Breed 125: 323-330. https://doi.org/10.1111/j.14390523.2006.01236.x

61. Tommey A, Evans E (1992) The influence of pre-floral growth and development, dry matter distribution and seed yield in oilseed rape (Brassica napus L.). Ann Appl Biol 121: 687-696. https://doi.org/10.1111/j.1744-7348.1992.tb03477.x

62. Vincent LA, Peterson TC, Barros VR, Marino MB, Rusticucci M, Carrasco G, Ramirez E, Alves LM, Ambrizzi T, Berlato MA, et al (2005) Observed trends in indices of daily temperature extremes in South America 1960-2000. J Clim 18: 5011-5023. https://doi.org/10.1175/JCLI3589.1 
63. Wahid A, Gelani S, Ashraf M, Foolad MR, Khair A (2007) Heat tolerance in plants: An overview. Environ Exp Bot 61: $199-223$. https://doi.org/10.1016/j.envexpbot.2007.05.011

64. Wardlaw IF, Wrigley CW (1994) Heat tolerance in temperate cereals: an overview. Aust J Plant Physiol 21: 695-703. https://doi.org/10.1071/PP9940695

65. Wardlaw IF, Moncur L (1995) The response of wheat to high temperature following anthesis. I. The rate and duration of kernel filling. Aust J Plant Physiol 22: 391-397. https://doi.org/10.1071/PP9950391

66. Wardlaw I, Blumenthal C, Larroque O, Wrigley C (2002) Contrasting effects of chronic heat stress and heat shock on kernel weight and flour quality in wheat. Funct Plant Biol 29: 25-34. https://doi.org/10.1071/PP00147

67. Wild M (2009) Global dimming and brightening: A review. J Geophys Res-Atmos 114: D00D16. https://doi.org/10.1029/2008JD011470

68. WMO (2008) World Meteorological Organization statement on the status of the global climate in 2008. https://library.wmo.int/doc_num.php?explnum_id=3461 last accessed December 192020

69. Wu W, Shah F, Duncan R W, Ma B L (2020) Grain yield, root growth habit and lodging of eight oilseed rape genotypes in response to a short period of heat stress during flowering. Agric For Meteorol 285: 107954.

https://doi.org/10.1016/j.agrformet.2020.107954

70. Yin X, Guo W, Spiertz JH (2009) A quantitative approach to characterize sink-source relationships during grain filling in contrasting wheat genotypes. Field Crops Res 114: 119-126. https://doi.org/10.1016/j.fcr.2009.07.013

71. Zhang H, Flottmann S (2016) Seed yield of canola (Brassica napus) is determined primarily by biomass in a high-yielding environment. Crop Pasture Sci 67: 369-380. https://doi.org/10.1071/CP15236

\section{Tables}

\section{Table 1}




\begin{tabular}{|c|c|c|c|c|c|c|c|c|c|}
\hline \multirow[t]{2}{*}{ Area } & Latitude & Longitude & Altitude & $\begin{array}{l}\text { Climate } \\
\text { series }\end{array}$ & Location & Country & $\begin{array}{l}\text { Planting } \\
\text { date }\end{array}$ & $\begin{array}{l}\text { Flowering } \\
\text { date }\end{array}$ & $\begin{array}{l}\text { Maturity } \\
\text { date }\end{array}$ \\
\hline & $\left({ }^{\circ} \mathrm{S}\right)$ & $\left({ }^{\circ} W\right)$ & (masl) & & & & & & \\
\hline \multirow{7}{*}{$\begin{array}{l}\text { North } \\
\text { (from } \\
23.30 \\
\text { to } \\
29.88^{\circ} \\
\text { S) }\end{array}$} & 23.30 & 51.16 & 566 & $\begin{array}{l}1976- \\
2018\end{array}$ & Londrina & Brazil & \multirow{7}{*}{$\begin{array}{l}\text { Mid of May } \\
\text { at the } \\
\text { beginning } \\
\text { of June }\end{array}$} & \multirow{7}{*}{$\begin{array}{l}\text { Mid of } \\
\text { September } \\
\text { at the } \\
\text { beginning } \\
\text { of October }\end{array}$} & \multirow{7}{*}{$\begin{array}{l}\text { Mid of } \\
\text { October } \\
\text { at the } \\
\text { beginning } \\
\text { of } \\
\text { November }\end{array}$} \\
\hline & 24.85 & 65.48 & 1221 & $\begin{array}{l}1961- \\
2018\end{array}$ & Salta & Argentina & & & \\
\hline & 25.39 & 51.46 & 1120 & $\begin{array}{l}1976- \\
2018\end{array}$ & Guarapuava & Brazil & & & \\
\hline & 27.78 & 64.26 & 201 & $\begin{array}{l}1961- \\
2018\end{array}$ & $\begin{array}{l}\text { Santiago del } \\
\text { Estero }\end{array}$ & Argentina & & & \\
\hline & 28.21 & 52.40 & 684 & $\begin{array}{l}1988- \\
2018\end{array}$ & Passo Fundo & Brazil & & & \\
\hline & 29.18 & 59.70 & 53 & $\begin{array}{l}1961- \\
2018\end{array}$ & Reconquista & Argentina & & & \\
\hline & 29.88 & 61.95 & 88 & $\begin{array}{l}1961- \\
2018\end{array}$ & Ceres & Argentina & & & \\
\hline \multirow{11}{*}{$\begin{array}{l}\text { Central } \\
\text { (from } \\
31.27 \\
\text { to } \\
34.55^{\circ} \\
\text { S) }\end{array}$} & 31.27 & 57.93 & 47 & $\begin{array}{l}1970- \\
2018\end{array}$ & Salto Grande & Uruguay & \multirow{11}{*}{$\begin{array}{l}\text { Beginning } \\
\text { to mid } \\
\text { June }\end{array}$} & \multirow{11}{*}{$\begin{array}{l}\text { End of } \\
\text { October } \\
\text { at the } \\
\text { beginning } \\
\text { of November }\end{array}$} & \multirow{11}{*}{$\begin{array}{l}\text { End of } \\
\text { November } \\
\text { at the } \\
\text { beginning } \\
\text { of } \\
\text { December }\end{array}$} \\
\hline & 31.70 & 60.82 & 18 & $\begin{array}{l}1961- \\
2018\end{array}$ & Sauce Viejo & Argentina & & & \\
\hline & 31.72 & 55.98 & 143 & $\begin{array}{l}1986- \\
2018\end{array}$ & Tacuarembó & Uruguay & & & \\
\hline & 32.69 & 62.10 & 114 & $\begin{array}{l}1961- \\
2018\end{array}$ & $\begin{array}{l}\text { Marcos } \\
\text { Juárez }\end{array}$ & Argentina & & & \\
\hline & 32.92 & 60.78 & 25 & $\begin{array}{l}1961- \\
2018\end{array}$ & Rosario & Argentina & & & \\
\hline & 33.00 & 58.62 & 21 & $\begin{array}{l}1962- \\
2018\end{array}$ & Gualeguaychú & Argentina & & & \\
\hline & 33.12 & 64.23 & 421 & $\begin{array}{l}1962- \\
2018\end{array}$ & Río Cuarto & Argentina & & & \\
\hline & 33.74 & 61.96 & 111 & $\begin{array}{l}1988- \\
2018\end{array}$ & $\begin{array}{l}\text { Venado } \\
\text { Tuerto }\end{array}$ & Argentina & & & \\
\hline & 34.13 & 63.37 & 137 & $\begin{array}{l}1961- \\
2018\end{array}$ & Laboulaye & Argentina & & & \\
\hline & 34.32 & 57.72 & 72 & $\begin{array}{l}1966- \\
2018\end{array}$ & La Estanzuela & Uruguay & & & \\
\hline & 34.55 & 60.92 & 81 & $\begin{array}{l}1961- \\
2018\end{array}$ & Junín & Argentina & & & \\
\hline \multirow{6}{*}{$\begin{array}{l}\text { South } \\
\text { (from } \\
35.70 \\
\text { to } \\
39.64^{\circ} \\
\text { S) }\end{array}$} & 35.70 & 63.75 & 141 & $\begin{array}{l}1961- \\
2018\end{array}$ & General Pico & Argentina & \multirow{6}{*}{$\begin{array}{l}\text { Beginning } \\
\text { of July at } \\
\text { the } \\
\text { beginning } \\
\text { of August }\end{array}$} & \multirow{6}{*}{$\begin{array}{l}\text { Beginning } \\
\text { to end } \\
\text { November }\end{array}$} & \multirow{6}{*}{$\begin{array}{l}\text { Mid to } \\
\text { end } \\
\text { December }\end{array}$} \\
\hline & 35.97 & 62.73 & 80 & $\begin{array}{l}1975- \\
2018\end{array}$ & $\begin{array}{l}\text { Trenque } \\
\text { Lauquen }\end{array}$ & Argentina & & & \\
\hline & 36.01 & 59.09 & 36 & $\begin{array}{l}1988- \\
2018\end{array}$ & Las Flores & Argentina & & & \\
\hline & 36.23 & 61.12 & 102 & $\begin{array}{l}1988- \\
2018\end{array}$ & Bolívar & Argentina & & & \\
\hline & 36.57 & 64.27 & 191 & $\begin{array}{l}1961- \\
2018\end{array}$ & Santa Rosa & Argentina & & & \\
\hline & 36.60 & 72.10 & 194 & 1983- & $\begin{array}{l}\text { Chillán } \\
\text { Page 14/24 }\end{array}$ & Chile & & & \\
\hline
\end{tabular}




\begin{tabular}{|c|c|c|c|c|c|}
\hline \multicolumn{6}{|c|}{2018} \\
\hline 36.77 & 59.85 & 137 & $\begin{array}{l}1961- \\
2018\end{array}$ & Azul & Argentina \\
\hline 36.89 & 60.32 & 162 & $\begin{array}{l}1988- \\
2018\end{array}$ & Olavarría & Argentina \\
\hline 37.23 & 59.25 & 175 & $\begin{array}{l}1971- \\
2018\end{array}$ & Tandil & Argentina \\
\hline 37.43 & 61.88 & 233 & $\begin{array}{l}1961- \\
2018\end{array}$ & $\begin{array}{l}\text { Coronel } \\
\text { Suárez }\end{array}$ & Argentina \\
\hline 37.60 & 62.38 & 304 & $\begin{array}{l}1962- \\
2018\end{array}$ & Pigué & Argentina \\
\hline 37.93 & 57.58 & 21 & $\begin{array}{l}1961- \\
2018\end{array}$ & Mar del Plata & Argentina \\
\hline 38.33 & 60.25 & 109 & $\begin{array}{l}1964- \\
2018\end{array}$ & Tres Arroyos & Argentina \\
\hline 38.73 & 62.17 & 83 & $\begin{array}{l}1961- \\
2018\end{array}$ & Bahía Blanca & Argentina \\
\hline 39.64 & 73.08 & 18 & $\begin{array}{l}1983- \\
2018\end{array}$ & Pichoy & Chile \\
\hline
\end{tabular}

Table 2 


\begin{tabular}{|c|c|c|c|}
\hline & & Cumulative probability & during post-flowering \\
\hline \multirow[t]{2}{*}{ Area } & Location & $\mathrm{T}>30^{\circ} \mathrm{C}$ & $\mathrm{T}+5^{\circ} \mathrm{C}$ \\
\hline & & plus R50\% & plus $\mathrm{R} 50 \%$ \\
\hline \multirow{7}{*}{$\begin{array}{l}\text { North } \\
\text { (from } 23.30 \text { to } 29.88^{\circ} \mathrm{S} \text { ) }\end{array}$} & Londrina & 0.65 & 0.04 \\
\hline & Salta & 0.36 & 0.17 \\
\hline & Guarapuava & 0.07 & 0.14 \\
\hline & Santiago del Estero & 0.62 & 0.16 \\
\hline & Passo Fundo & 0.29 & 0.38 \\
\hline & Reconquista & 0.43 & 0.26 \\
\hline & Ceres & 0.37 & 0.13 \\
\hline \multirow{11}{*}{$\begin{array}{l}\text { Central } \\
\text { (from } 31.27 \text { to } 34.55^{\circ} \mathrm{S} \text { ) }\end{array}$} & Salto Grande & 0.39 & 0.21 \\
\hline & Sauce Viejo & 0.23 & 0.18 \\
\hline & Tacuarembó & 0.13 & 0.25 \\
\hline & Marcos Juárez & 0.19 & 0.14 \\
\hline & Rosario & 0.07 & 0.09 \\
\hline & Gualeguaychú & 0.34 & 0.31 \\
\hline & Río Cuarto & 0.44 & 0.46 \\
\hline & Venado Tuerto & 0.47 & 0.12 \\
\hline & Laboulaye & 0.22 & 0.06 \\
\hline & La Estanzuela & 0.04 & 0.19 \\
\hline & Junín & 0.32 & 0.08 \\
\hline \multirow{15}{*}{$\begin{array}{l}\text { South } \\
\text { (from } 35.70 \text { to } 39.64^{\circ} \mathrm{S} \text { ) }\end{array}$} & General Pico & 0.24 & 0.00 \\
\hline & Trenque Lauquen & 0.63 & 0.07 \\
\hline & Las Flores & 0.25 & 0.15 \\
\hline & Bolívar & 0.24 & 0.08 \\
\hline & Santa Rosa & 0.19 & 0.03 \\
\hline & Chillán & 0.00 & 0.00 \\
\hline & Azul & 0.25 & 0.12 \\
\hline & Olavarría & 0.22 & 0.14 \\
\hline & Tandil & 0.22 & 0.13 \\
\hline & Coronel Suárez & 0.19 & 0.04 \\
\hline & Pigué & 0.36 & 0.07 \\
\hline & Mar del Plata & 0.48 & 0.00 \\
\hline & Tres Arroyos & 0.40 & 0.18 \\
\hline & Bahía Blanca & 0.54 & 0.07 \\
\hline & Pichoy & 0.00 & 0.00 \\
\hline
\end{tabular}




\section{Figures}

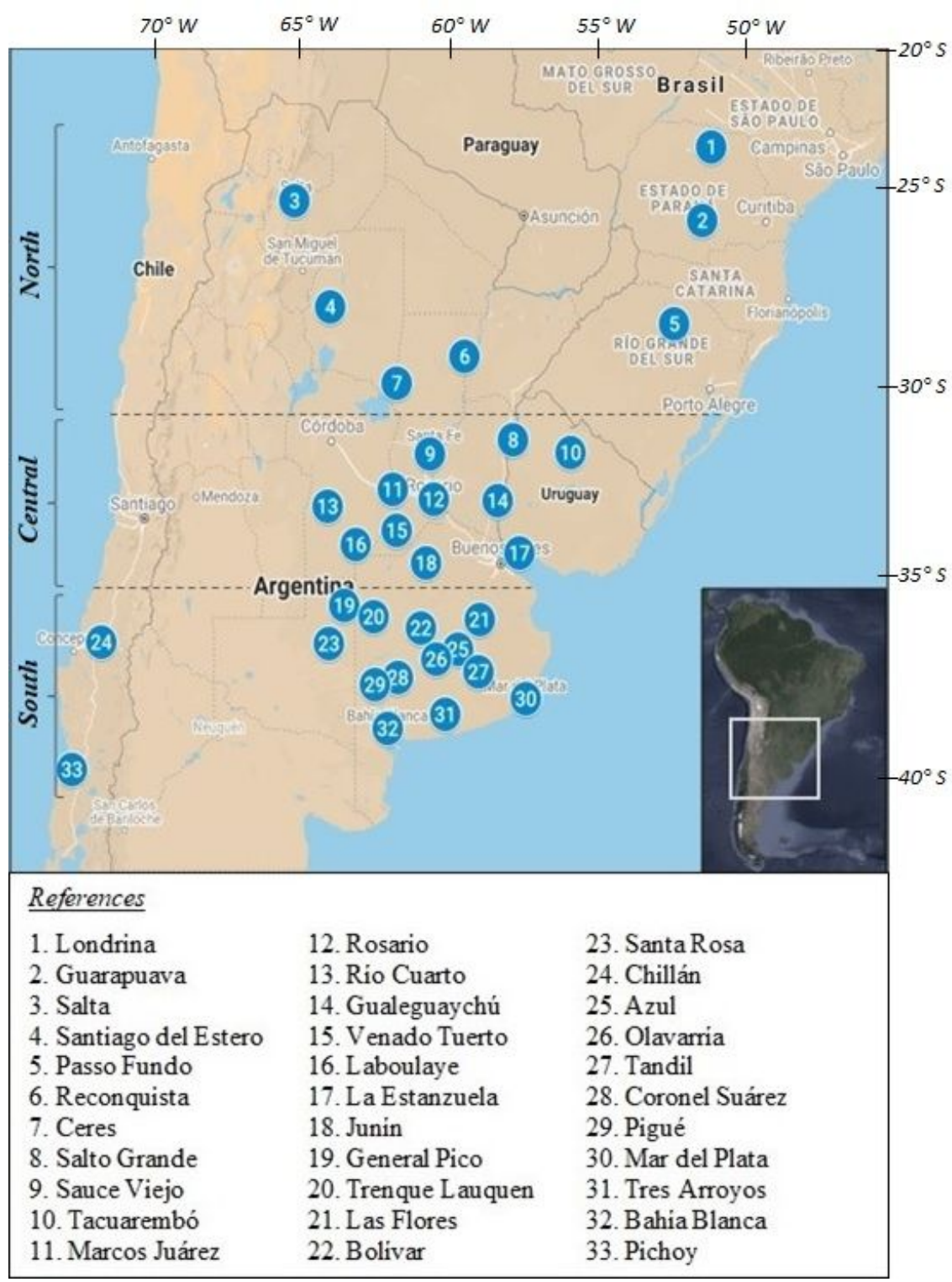

\section{Figure 1}

Map of the Southern Cone of South America divided into north, central and south areas (delimited by horizontal striped lines) with the analysed locations. (Source: http://maps.google.com/) Note: The designations employed and the presentation of the material on this map do not imply the expression of any opinion whatsoever on the part of Research Square concerning the legal status of any country, territory, city or area or of its authorities, or concerning the delimitation of its frontiers or boundaries. This map has been provided by the authors. 


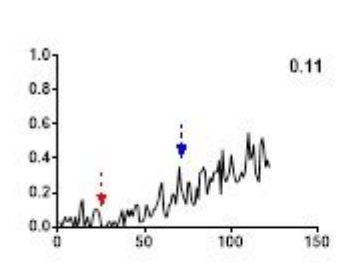

Passo fundo, Brazll $\left(28.21^{\circ} \mathrm{S}, 52.40^{\circ} \mathrm{W}\right)$
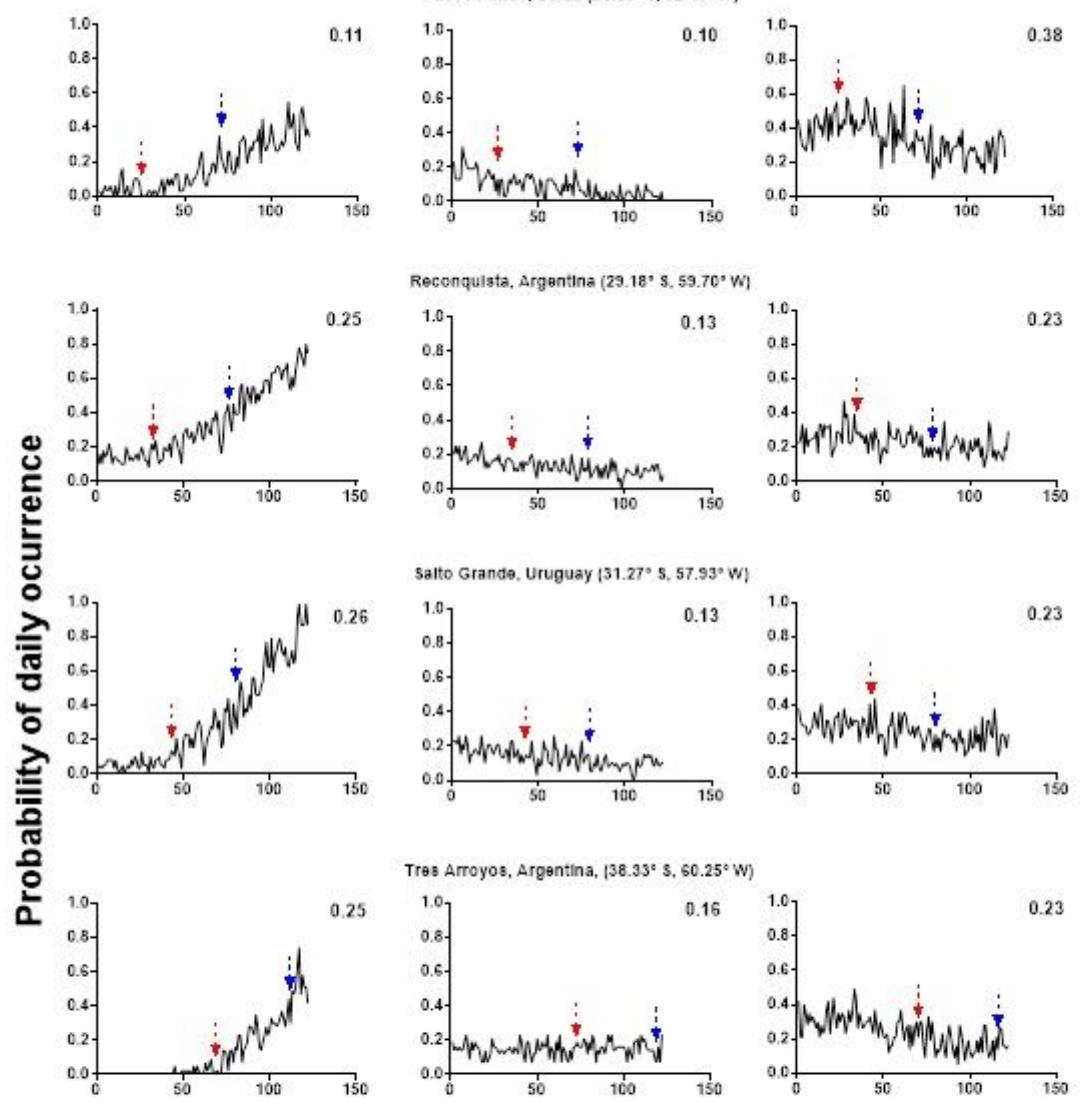

Salto Grande, Uruguay $\left[31.27^{\circ} \mathrm{S}, 57.93^{\circ} \mathrm{W}\right)$
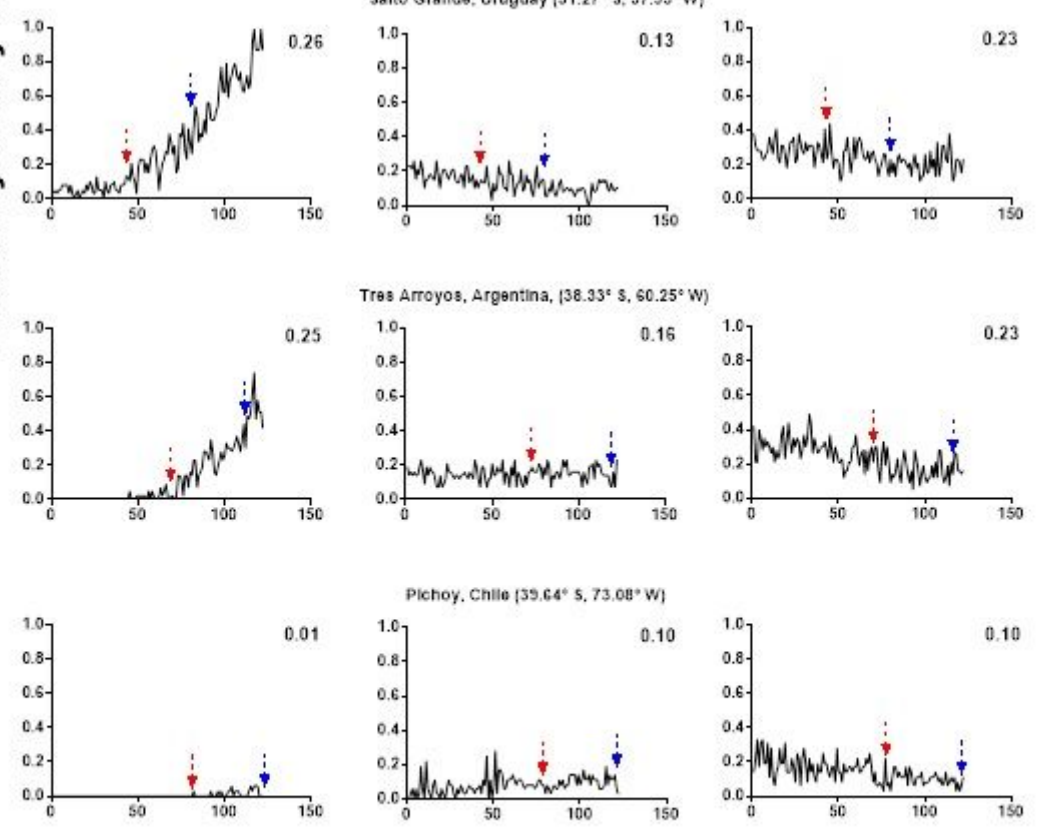

Days from September $1^{\text {st }}$

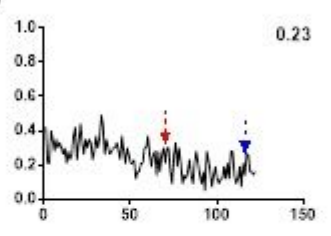

\section{Figure 2}

Probabilities of daily occurrence of individual high temperature events: maximum daily temperatures above $30^{\circ} \mathrm{C}\left(\mathrm{T}>30^{\circ} \mathrm{C}\right.$, left panels) and increase of $5^{\circ} \mathrm{C}$ above the daily maximum historical average $\left(T+5^{\circ} \mathrm{C}\right.$, central panels), and cloudiness events: global solar radiation $\leq 50 \%$ the historical daily average radiation (R50\%, right panels) as a function of the days from September 1 st in representative locations of the Southern Cone of South America. The arrows on the x-axis indicate the typical dates of flowering (red arrow) and physiological maturity (blue arrow) for wheat and canola. The values at the top right of each graph represent average probability during post-flowering period 


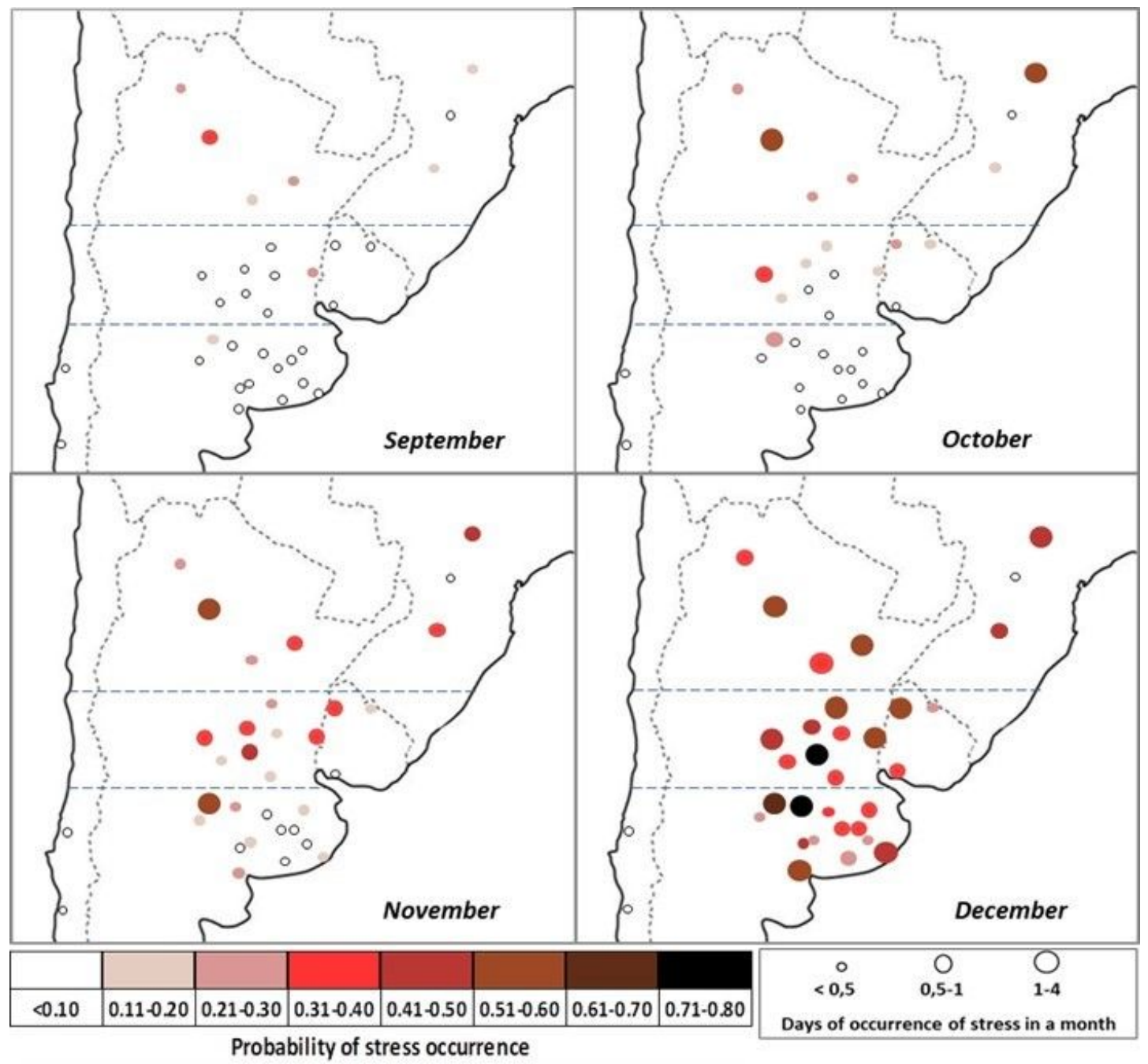

Figure 3

Monthly probability of occurrence of the combined stress of heat and cloudiness, $\mathrm{T}>30^{\circ} \mathrm{C}$ plus R $50 \%$, in locations of the Southern Cone of South America. The colour of the circle goes from the lightest to the darkest in relation to the increased probability. The diameter of the circles is proportional to the number of days under combined events in a month. Horizontal striped lines delimit north, central and south areas Note: The designations employed and the presentation of the material on this map do not imply the expression of any opinion whatsoever on the part of Research Square concerning the legal status of any country, territory, city or area or of its authorities, or concerning the delimitation of its frontiers or boundaries. This map has been provided by the authors. 


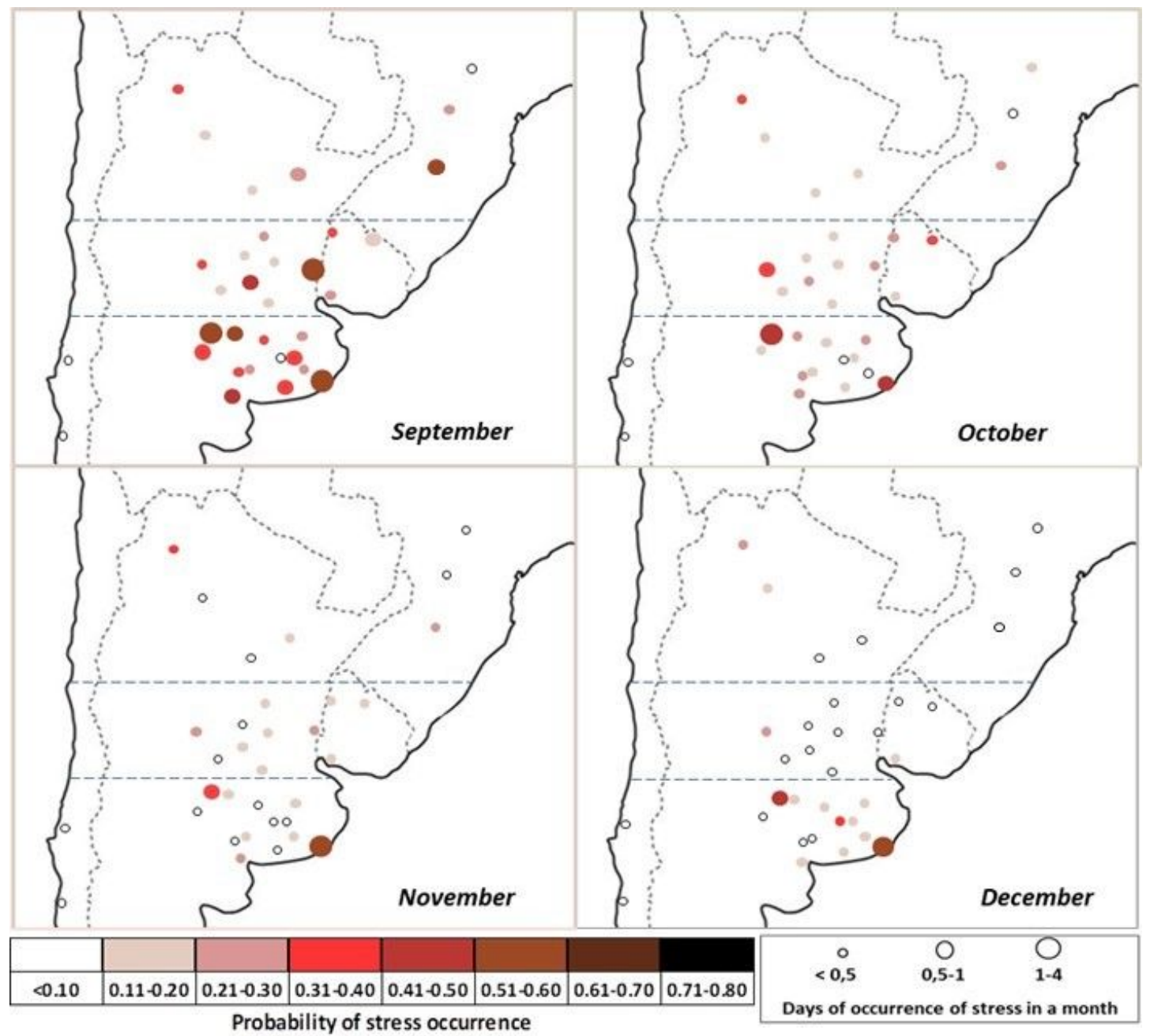

Figure 4

Monthly probability of occurrence of the combined stress of heat and cloudiness, $T+5^{\circ} \mathrm{C}$ plus $\mathrm{R} 50 \%$, in locations of the Southern Cone of South America. The colour of the circle goes from the lightest to the darkest in relation to the increased probability. The diameter of the circles is proportional to the number of days under combined events in a month. Horizontal striped lines delimit north, central and south areas Note: The designations employed and the presentation of the material on this map do not imply the expression of any opinion whatsoever on the part of Research Square concerning the legal status of any country, territory, city or area or of its authorities, or concerning the delimitation of its frontiers or boundaries. This map has been provided by the authors. 

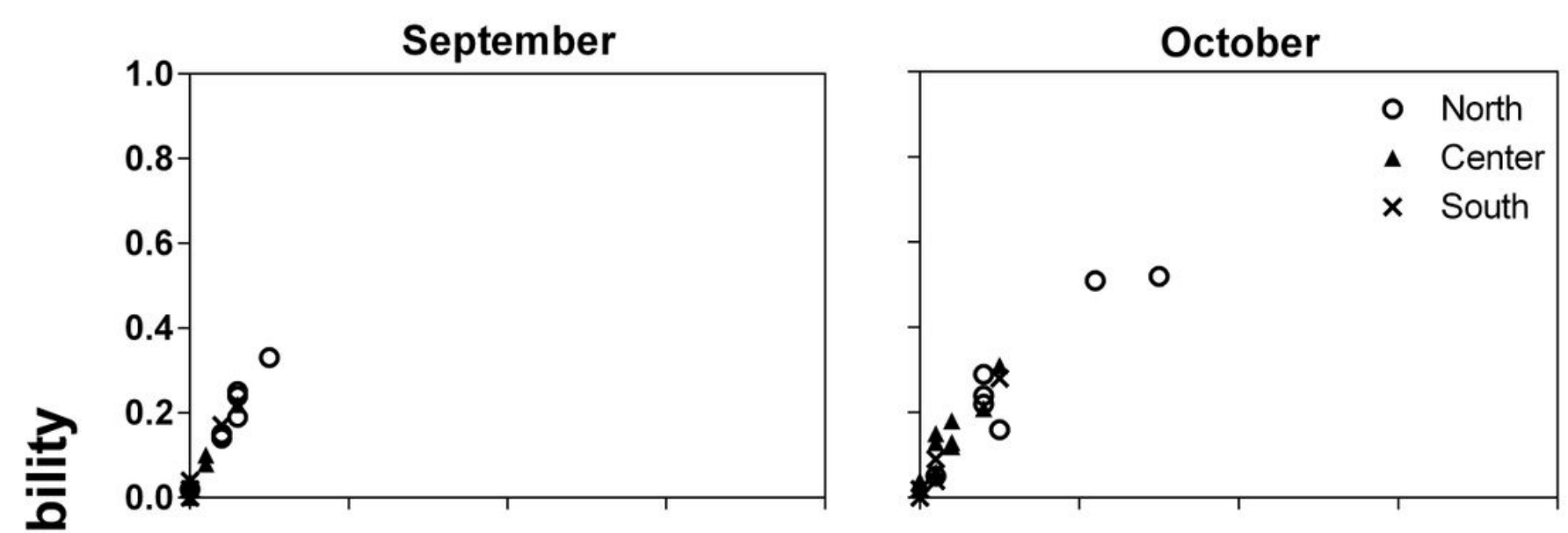

응
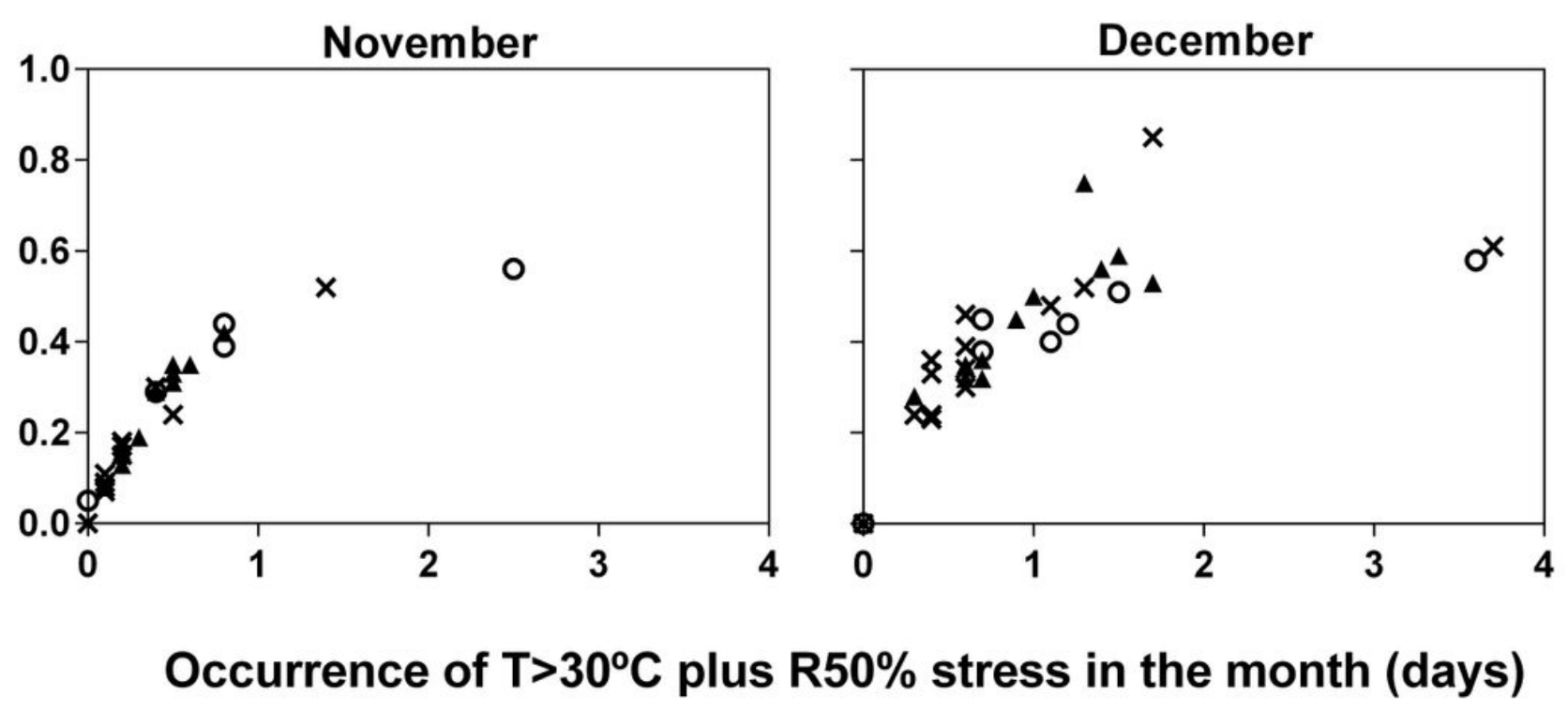

Figure 5

Scatter plot of monthly probability of occurrence of the combined stress of heat and cloudiness $T>30^{\circ} \mathrm{C}$ plus $\mathrm{R} 50 \%$ and the number of days with the stress for all locations ( $n=33$ ) of north (circles), central (triangles) and south (cross) areas of the Southern Cone of South America 

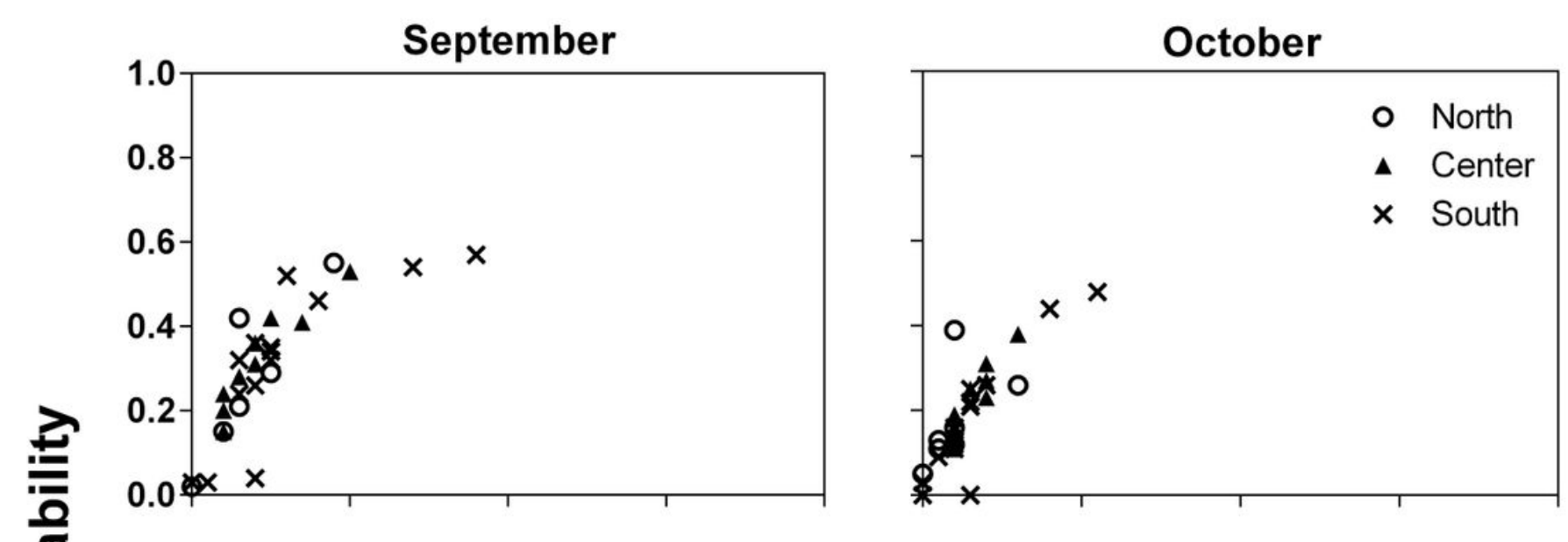

은
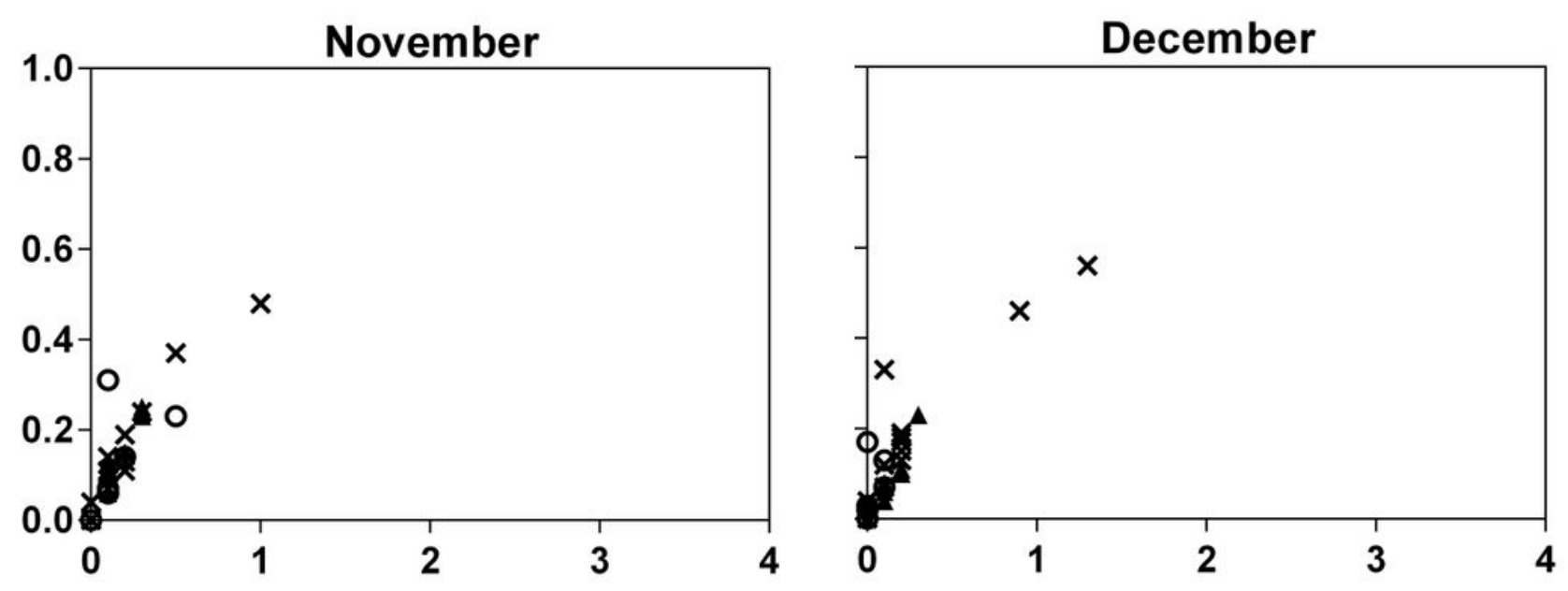

Occurrence of $\mathrm{T}+5^{\circ} \mathrm{C}$ plus $\mathrm{R} 50 \%$ stress in the month (days)

Figure 6

Scatter plot of monthly probability of occurrence of the combined stress of heat and cloudiness $\mathrm{T}+5^{\circ} \mathrm{C}$ plus $\mathrm{R} 50 \%$ for all locations $(n=33)$ of north (circles), central (triangles) and south (cross) areas of the Southern Cone of South America 

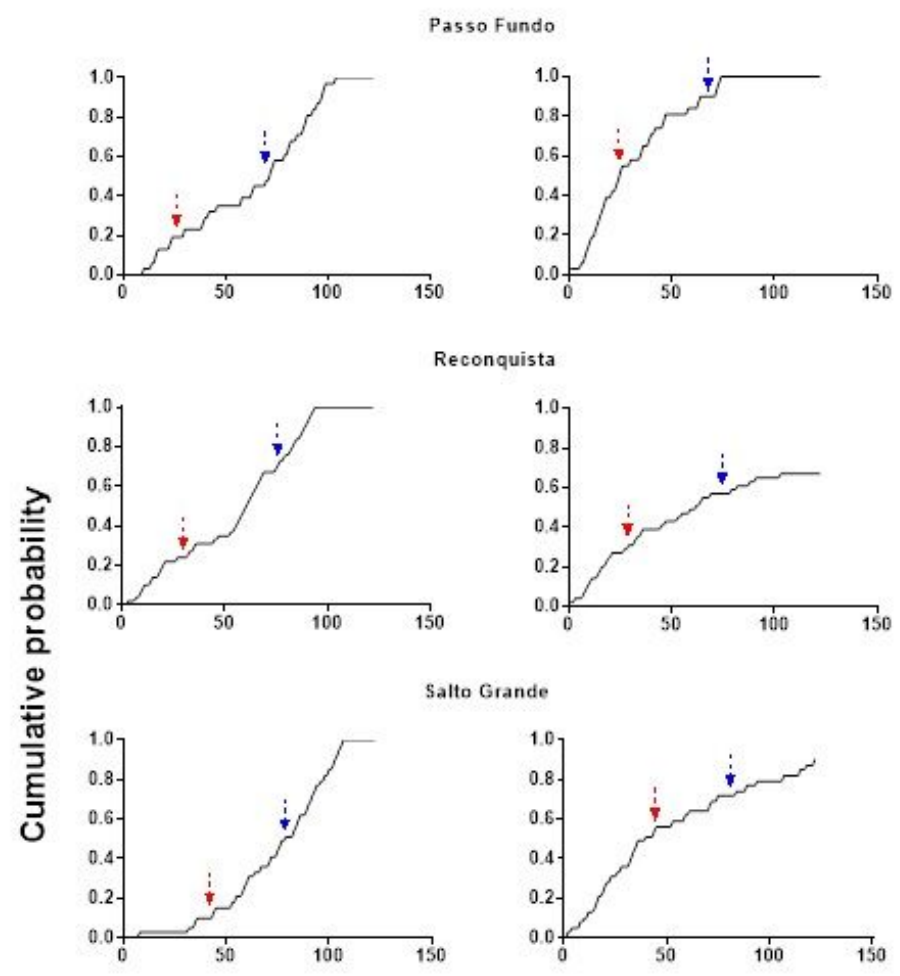

Salto Grande

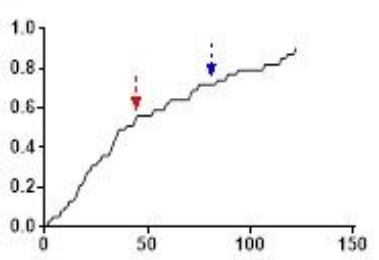

Tres Arroyos

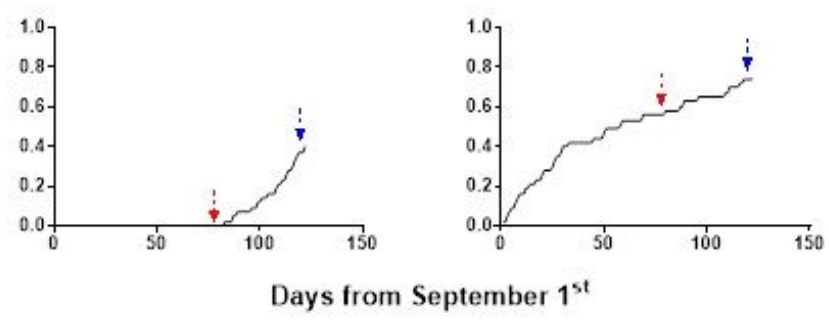

\section{Figure 7}

Cumulative probabilities of combined stress of heat and cloudiness as a function of days from September 1st to representative locations in the Southern Cone of South America. The arrows on the x-axis indicate the typical time of flowering (red arrow) and physiological maturity (blue arrow) of wheat and canola

\section{Supplementary Files}

This is a list of supplementary files associated with this preprint. Click to download.

- FigS1.jpg

- FigS2.jpg

- FigS3.jpg

- FigS4.jpg

- FigS5.jpg

- FigS6.jpg

- FigS7.jpg

- FigS8.jpg

- FigS9.jpg 
- FigS10.jpg

- Tables1.xlsx

Page 24/24 